\title{
Apatite multi-generations in the Três Estradas Carbonatite, Southern Brazil: physical and chemistry meaning and implications to phosphate ore quality
}

\author{
Henrique de Maman Anzolin 1* (D), Norberto Dani' (D), Marcus Vinícius Dorneles Remus' (D), \\ Rafael da Rocha Ribeiro' (D), Alfredo Rossetto Nunes ${ }^{2}$ (D), Kelvyn Mikael Vaccari Ruppel' (D)
}

\begin{abstract}
Carbonatites were recently discovered in Southern Brazil, which increased the interest to evaluate the economic potential of these uncommon rocks, especially the Três Estradas Carbonatite. Carbonates are the dominant minerals of fresh rock followed by apatite, but the weathering process makes apatite abundant. We focused on apatite from the carbonatite using conventional petrography and electronic microscopy associated with microprobe, micro-Raman and Fourier-transform infrared spectroscopy. Results demonstrate the existence of four types. The primary type is associated with the rock crystallization and the subsequent three others are associated with weathering processes. The alteration mechanism was favorable for initial carbonate leaching and subsequent increase of phosphate with late precipitation of three new apatite generations. The deduced model involves long exposure during polycyclic climate changes, intercalating periods of warm dry with humid climate. The apatite types differ chemically and morphologically and have distinctive characteristics that are suitable to be used to differentiate them. These properties should be considered in future planes of industrial processes to transform apatite into single superphosphate, a basic input for fertilizer production.
\end{abstract}

KEYWORDS: Carbonatite; geochemistry; phosphate; apatite.

\section{INTRODUCTION}

The recent identification of carbonatites in the Southern Rio-Grandense Shield increased the Southern Brazil potential to make investments directed to the production of agricultural raw material (fertilizers) or to apply them in high technology using elements normally enriched in these rocks, such as the rare earth elements (REE). To define these possibilities of carbonatite, we obtained mineralogical and chemical data. The objective of this paper is to study the apatite, a mineral that concentrates phosphates in the rock, and the weathering profile. Apatite constitutes the target mineral to industrial use of Três Estradas Carbonatite.

In the Southern Rio-Grandense Shield, the first piece of evidence that indicated the existence of rocks from the carbonatite group was observed from airborne geophysics and surface geochemical survey (stream sediments and soil analysis), implemented by Companhia Brasileira do Cobre (CBC) and Companhia de Pesquisas em Recursos Minerais (CPRM) (Parisi et al. 2010, Toniolo et al. 2010, Grazia et al. 2011, Toniolo et al. 2013). After such discovery, new carbonatites

${ }^{1}$ Universidade Federal do Rio Grande do Sul - Porto Alegre (RS), Brazil. E-mails: henriqueanzolin@hotmail.com, kelvynruppel@gmail.com, norberto.dani@ufrgs.br, marcus.remus@ufrgs.br, r.ribeiro@ufrgs.br

${ }^{2}$ Águia Fertilizantes S.A. - Belo Horizonte (MG), Brazil.

E-mail: anunes@aguiafertilizantes.com.br

${ }^{*}$ Corresponding author. were identified in other sectors of Southern Rio-Grandense Shield, mostly Caçapava do Sul (Picada dos Tocos Carbonatite), about $70 \mathrm{~km}$ distant from the Três Estradas Carbonatite (Rocha et al. 2013, Cerva-Alves et al. 2017), which make a new carbonatite province in Brazil together with Joca Tavares occurrence. Três Estradas Carbonatite (TEC) is associated with the old gneiss of the Santa Maria Chico Granulite Complex (GCSMC) formed by Neoarchean to Neoproterozoic rocks and inserted in the Rio de La Plata Craton (Almeida 1967, Nardi \& Hartmann 1979, Almeida et al. 1981, Cordani \& BritoNeves 1982, Hartmann 1998, Hartmann et al. 2000, Philipp et al.2016). The TEC occurrence has a piece of evidence from processes of deformation and metamorphism (Toniolo et al. 2010, Toniolo et al. 2013, Águia Resources Limited, 2015, 2017), but the geological relation with the GCSMC and with the Passo da Capela Alkaline Province continue to be uncertain (Burger et al. 1988). Several occurrences of Cretaceous carbonatite rocks are known in the central-southern region of Brazil (Gomes et al.2018). A recent paper on Picada dos Tocos Carbonatite (Caçapava do Sul) shows U-Pb crystallization age of 603.2 \pm 4.5 My (Cerva-Alves et al. 2017). The attribution of this age to the TEC context with the present data is only a possibility reinforced by the observed field and similarities of rock features.

Carbonatite is a proto-ore due to its unusual composition. The weathering of TEC, particularly, produced a highly enriched product, with typical phosphate ore grade. The exposition of these rocks to periods of favorable climate, such as in tropical and subtropical wet regions of southern Brazil during the 
major part of the Cenozoic, enabled the formation of a thick weathering profile (Walter et al. 1995, Oliveira \& Imbernon 1998). Weathering of local rocks with uncommon composition, such as carbonatites, promoted preferential carbonate dissolution, removing magnesium and calcium from the rocks and gradually acidifying the percolating solutions. This condition destabilized the apatite and introduced phosphorus directly into the biologic cycle or formed new mineral phases, such as secondary apatite or aluminum-phosphates (Altschuler 1973, Toledo et al. 2004, Lapido-Loureiro et al. 2005). The history of this long TEC transformation process with the weathering is unfolded in this research using the characteristics observed on the four identified apatite generations. This is the major mineral of the studies for the economic exploitation of TEC.

\section{Localization and geologic framework of the area}

Três Estradas area is in Rio Grande do Sul State, at approximately $30 \mathrm{~km}$ southwest of the town of Lavras do Sul, Southern Brazil (Fig. 1A). Geologically, TEC is associated with lithologies of an old terrain in the Southern Rio-Grandense Shield named Taquarembó Block, characterized by Neoarchean rocks of the SMCGC (Fig. 1B). In the TEC domain (Fig. 1C), regional structures occur, such as Cerro dos Cabritos Fault Zone and Ibaré Lineament (Jost \& Hartmann 1984, Naumann et al. 1984, Iglesias 2000, Goulart 2014, Philipp et al. 2017, Ruppel et al. 2018), which are marked by complex evolution and reactivation episodes (Luzardo \& Fernandes 1990, Fernandes et al. 1992, Laux 2017). Ibaré Lineament is a shear zone that divides the Southern Rio-Grandense Shield into the large structural units of Taquarembó and São Gabriel blocks (Hartmann 1998, Chemale Jr. 2000)

Carbonatite outcrops in the TrêsEstradas area are rare. They usually occur as small bodies in drainage valleys or crests when associated with quartz veins. The best visualization of carbonatite distribution and relations to enclosed rocks was facilitated through a drilling program by Águia Resources Limited. The resulting subsurface model displays carbonatite as elongated lens with NE-SW direction, forming a synform-folded structure associated with fenite and amphibolite, as seen in Figure 2A (Águia Resources

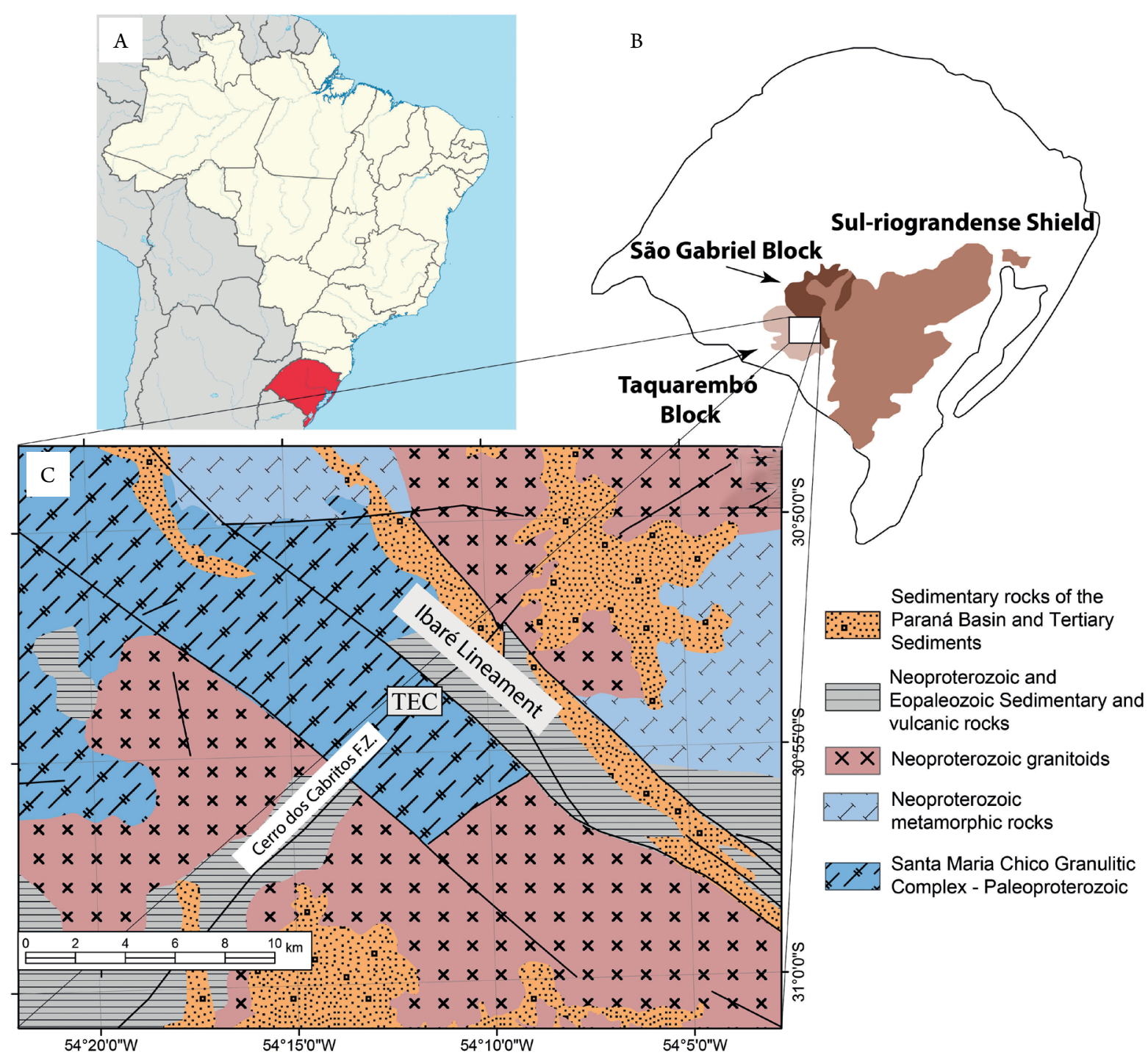

Figure 1. Localization of the studied area. (A) Map of South America showing Brazil and Rio Grande do Sul State. (B) Localization of the Sul-Rio-Grandense Shield in Rio Grande do Sul State, showing the São Gabriel and Taquarembó Blocks on the west side. (C) Geological map of the region of Três Estradas carbonatite, inserted in the GCSMC and delimited by the Ibaré Lineament - which limits the São Gabriel and Taquarembó Blocks - and Cerro dos Cabritos fail zone. (Modified from CPRM 2006 and Gastal and Ferreira 2013). 
Limited, 2015, 2017). On average, the observed weathering mantle has thickness estimated at $15 \mathrm{~m}$ and is formed by high-grade phosphates composed by residual and supergene apatite (Anzolin 2015). Detailed drilling investigations defined two flanks, highly dipping to the NW and following the general gneiss structure (Fig. 2B). Each flank of carbonatite has a 50-m thickness that is mostly intercalated with amphibolite. Identification of fenite suggests an intrusive process of carbonatite into SMCGC rocks and must be considered in further surveys (Figs. 2B and 2C).

\section{MATERIALS AND METHODS}

In this paper, samples of fresh and weathered carbonatite were collected either from drill core or in outcrops of the weathering profile. Subsurface samples of unaltered carbonatite (TED16) were collected from the directional drill hole TED 11-016 (Fig. 2C). Considering the inclination angle of the drill hole in relation to the horizontal plane, fresh samples were collected at a depth of about 50 meters. TED01T and TED02T altered samples were collected in the

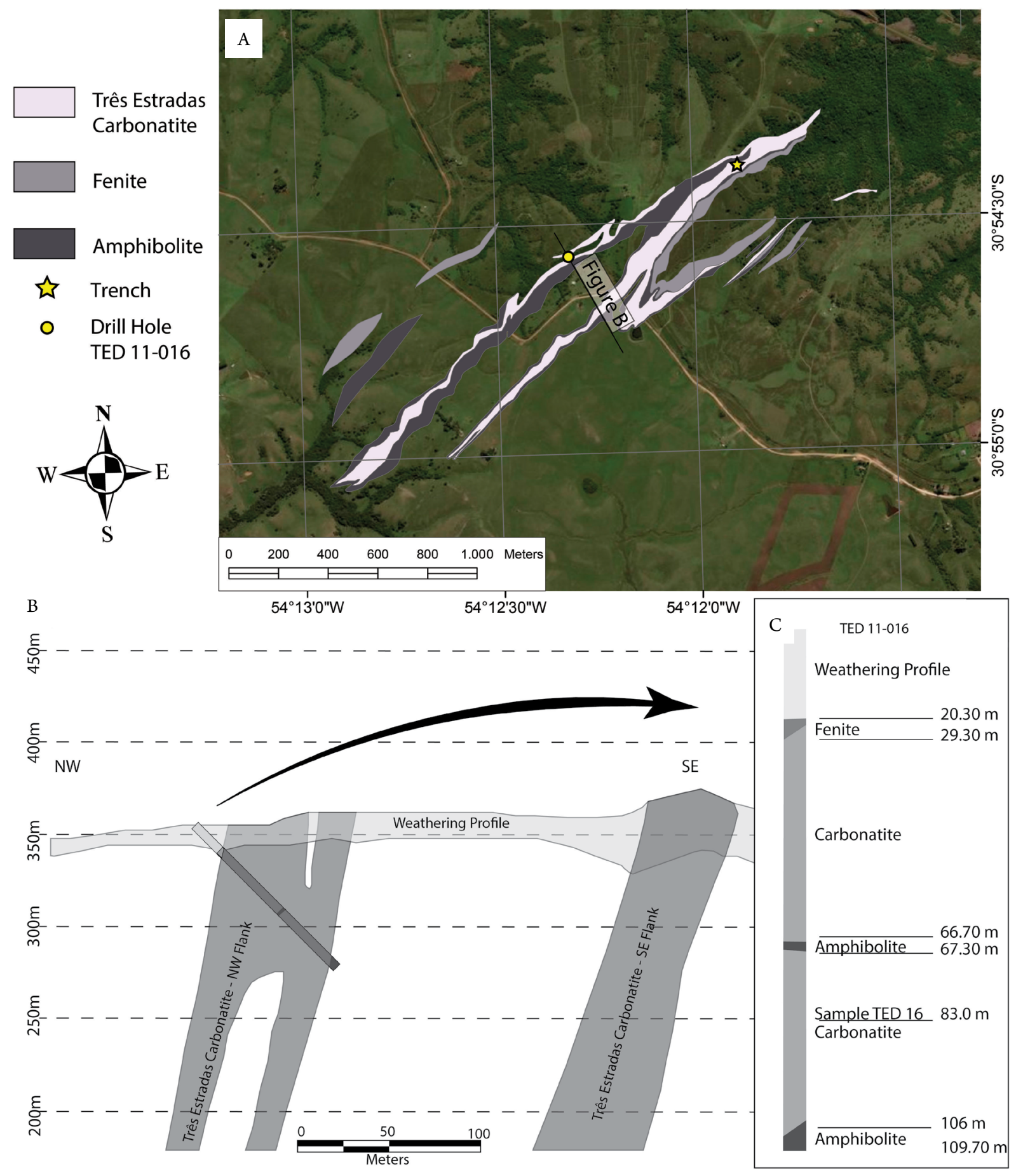

Figure 2. Três Estradas Carbonatite (TEC) occurrence. (A) Disposition of the carbonatite in the form of a folded elongated body in the NESW direction interleaved with fenites and amphibolite and the points of sample collection, as well as the disposition of the profile shown in Figure 2B that contains the drill hole TED 11-016. (B) Vertical profile approximately orthogonal to the fold hinge, showing the disposition of the dipping carbonatite bodies. (C) Disposition of the drill role used in this study with the sampling position and the lithotypes observed on the profile and the fenitization zones (modified from Águia Resources Limited 2015 and 2017, Esri 2009). 
weathering profile of the TEC directly at the base of a trench opened in the terrain.

Petrography was performed with a Leitz Aristomet microscope, using thin sections of the samples TED 16 and TED01T. Mineralogy was also determined through X-ray diffraction (XRD), applying the technique of total powder sample pulverized at 200 mesh, in a Siemens/Bruker equipment model D5000 with a goniometer $\theta-\theta$ in $45 \mathrm{kV}$ and $40 \mathrm{~mA}$ energy conditions, with scanning in the range from 3 to $50^{\circ} 2 \theta$, step size of $0.04^{\circ} 2 \theta$ and step time of three seconds.

Chemical analyses of the samples were carried out through the X-ray fluorescence spectrometry technique (XRF), using the vitreous disc method. Pulverized samples at a grain size of 200 mesh were fused with a proportion of 7,000 $\mathrm{g}$ of lithium tetraborate $\left(\mathrm{LiBO}_{2}\right)$ to $1,000 \mathrm{~g}$ of the sample. The sample disc was fused in a Panalytical oven, Eagon 2 model. Data were obtained using an XRF spectrometer Rigaku, model RIX2000, following the method of calibration curves obtained from a set of rock standards with international certification.

Minerals were analyzed by electron microprobe using the Cameca ${ }^{\circledR}$ SXfive equipment. Apatite analyses followed the methodology established by Walter et al. (1995) and Ferrari (2000). The concentration of $\mathrm{Na}, \mathrm{Si}, \mathrm{Mg}, \mathrm{Al}, \mathrm{P}, \mathrm{Cl}, \mathrm{Ca}, \mathrm{Ba}, \mathrm{K}, \mathrm{Mn}, \mathrm{Fe}$ and Sr were quantitatively determined in apatite using an energy level of $15 \mathrm{keV}, 15 \mathrm{nA}$ with a spot size of $5 \mu \mathrm{m}$. To minimize volatilization by electron beam heating, fluorine was initially measured with the spot size of $25 \mu \mathrm{m}$. The analyses of Ce and La were done at the end with higher energy condition $(15 \mathrm{keV}$, $40 \mathrm{nA}$ with spot size of $5 \mu \mathrm{m}$ ). Counts of element lines found in apatite were calibrated using standards, and measurements were converted into concentrations with the ZAF correction. The $\mathrm{OH}$ amount was estimated through stoichiometry.

The micro-Raman spectrometry was undertaken using a Horiba iHR320 equipped with a charged couple device (CCD) detector Symphony, which was refrigerated with liquid nitrogen. The laser used for the excitation was $\mathrm{HeNe}$ type, with wavelength of $632.8 \mathrm{~nm}$ and $10 \mathrm{~mW}$ of power, for an acquisition time from 20 to 30 seconds and with a focus capacity with diameter of approximately $3 \mu \mathrm{m}$. Spectra were obtained in two energy intervals, between 580 and $1,760 \mathrm{~cm}^{-1}$ of wave number, a region where the main absorption of $\mathrm{PO}_{4}$ and $\mathrm{CO}_{3}$ groups is produced and in the interval between 2,983 and $3,780 \mathrm{~cm}^{-1}$, related to $\mathrm{OH}$ absorption. The analysis by Fourier-transform infrared spectrometry (FTIR) was performed with a Shimadzu IR prestige 21 spectrometer. Samples were prepared in $\mathrm{KBr}$ discs, in which $0.0070 \mathrm{~g}$ of the sample (apatite) was pressed together with $0.100 \mathrm{~g}$ of $\mathrm{KBr}$, both macerated into homogeneous powder. Pressure conditions were $15 \mathrm{kgf}$ during four minutes, $20 \mathrm{kgf}$ for three minutes and $30 \mathrm{kgf}$ in the last three minutes, totaling ten minutes of pressing for each sample. The FTIR acquisitions of pressed discs were made in the wave number interval between 4,000 and $400 \mathrm{~cm}^{-1}$.

A Jeol JSM-6610 scanning electron microscope (SEM) was used to produce images of secondary electrons (SE) assisted by EDS spot analyses. Images were obtained from small fragments of the samples covered with carbon and gold coats.

\section{Mineralogy and geochemistry of TEC and weathering products}

Mineral composition of non-altered TEC shows the predominance of carbonates (85\%) and, in this group, dolomite is the main mineral followed by apatite ( $8 \%$ ), opaque minerals (5\%), especially magnetite, hematite and accessory minerals (2\%), in which minor quantities of tremolite-actinolite, phlogopite, talc, titanite and zircon are present. The samples have carbonate bands intercalated with others richer in opaque minerals, apatite, tremolite-actinolite and phlogopite. Minerals vary from anhedral to subhedral, in which apatite has dimensions lower than $0.5 \mathrm{~mm}$, wavy extinction and frequently with fractures filled with carbonates. XRD displayed the predominance of dolomite in relation to calcite (Fig. 3). Semi-quantitatively, the proportion of calcite to dolomite in TEC was evaluated by XRD through the integration of the area of 104 diffraction planes (3,035 ̊̊ for calcite and 2,888 Å for dolomite), which allowed the estimate of calcite in a proportion lower than $5 \%$ of the total volume of the TED 016 sample (Fig. 3).

TEC mineralogical and chemical composition presents similarities with Picada dos Tocos metacarbonatite, described in Caçapava do Sul region, especially with the beforsite type (Cerva-Alves et al.2017). The TEC was distinguished through the high levels of $\mathrm{MgO}$ and $\mathrm{P}_{2} \mathrm{O}_{5}$ (Fig. 4). Sodium and potassium were not detected through the XRF analysis (Fig. 5), and this absence or low concentration are common in this rock and were observed in other occurrences of carbonatites (Barker \& Nixon 1989, Ignacio et al. 2012, Cerva-Alves et al. 2017).

On TEC, the weathering profile is characterized through the sharp evolution from fresh to altered rock, and altered TEC samples are marked by intense carbonate dissolution. Magnesium and calcium originally related to carbonates were removed, while silica, manganese, iron, aluminum and titanium were accumulated (Fig. 5). The general organization of the weathering profile presents, at the base, a large saprolite zone with brown color and the preservation of the gneissic structure followed by a thin organic soil horizon on the top (Anzolin 2015).

In the TEC weathering profile, due to the preferential carbonate dissolution, apatite that originally has an $8 \%$ proportion in the rock, was gradually concentrated and became the main mineral, followed by iron oxides and hydroxides like hematite and goethite and, in minor proportion, silicates such as clay minerals (Fig. 3 - TED 01T and TED 02T). Secondary iron minerals formed indurated crusts and thin layers, resulting in a hard framework that sustains the erosion of the entire profile despite the expressive number of voids generated by carbonate dissolution. The increased participation of apatite in the altered rock is supported by petrography (Fig. 6) and XRD (Fig. 3) analyses. When fresh carbonatite composition is compared to altered samples, the notable enrichment in apatite during weathering is chemically marked by a pronounced increase of $\mathrm{P}_{2} \mathrm{O}_{5}$ (evolving from $4 \mathrm{wt} \%$ in fresh rock to $25 \mathrm{wt} \%$ in altered carbonatite) and through calcium stabilization. $\mathrm{Mg}$ decrease reinforces the mineralogical changes observed in the samples that characterize the carbonate dissolution (mostly dolomite) in the rock (Fig. 5). 


\section{Apatite occurrence and texture}

In this paper, observations made using optical microscopy complemented by SEM identified four different types of apatite and relations with other constituents. The first type originated with rock crystallization is found in unaltered carbonatite; primary apatites (Type 1) occur as equigranular crystals with subhedral to anhedral form, with individual grains with $1 \mathrm{~mm}$ size, concentrated in rock bands in association with opaque minerals or in fractures often filled by carbonates (Figs. 6A and 6B). In weathered carbonatite, apatite type 1 is gradually modified giving place to altered apatite (Type 2), which evolved from the partial alteration of primary apatite (Type 1). The alteration process is characterized by the formation of a set of isolated nuclei with dissolved edges, each up to $200 \mu \mathrm{m}$ (Figs. 6C, 6D and 6F). Associated with type 2 (altered apatite), a new generation of apatite is developed (Type 3) following the same crystallographic orientation of the previous type 2, forming euhedral crystals (Figs. 6C, 6D, $6 \mathrm{~F}$ and 7 ) that grow in continuity to type 2 (epitaxial growth). Characteristically, type 3 apatites are marked by the presence of inclusions formed by iron oxides with a fringe that marks epitaxial growth (Fig. 6D). The youngest apatite type identified in the weathering profile occurs as small euhedral crystallites (Type 4) up to $50 \mu \mathrm{m}$, normally covering type 3 apatite (Figs. 6C, $6 \mathrm{D}, 6 \mathrm{~F}$ and 7 ) in radial aggregates (Fig. 6E), in veins or filling voids generated by dissolved carbonates (Figs. $6 \mathrm{G}$ and $6 \mathrm{H}$ ).
The youngest generation of phosphate minerals was observed through a detailed SEM analysis that allowed the identification of aluminum-phosphates, minerals typically associated with weathered phosphate rocks (Fig. 7). The identification of $P$, $\mathrm{Al}, \mathrm{Ca}$ and $\mathrm{Ba}$ (SEM-EDS analyses) shows compatibility with minerals of the crandalite mineral group (Fig. 8). Induced by

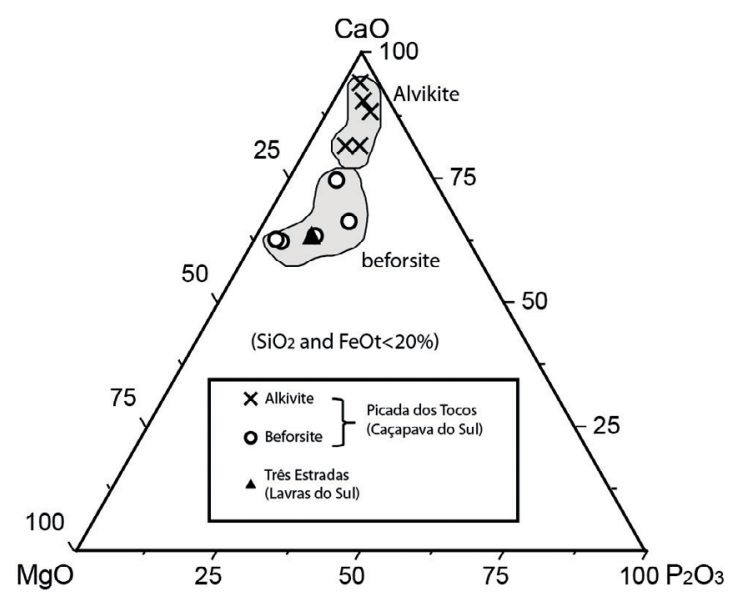

Figure 4. Ternary diagram of the composition (in wt\%) of the $\mathrm{CaO}$, $\mathrm{MgO}$ and $\mathrm{P}_{2} \mathrm{O}_{3}$ concentration of the sample TED016 (TEC) and the results obtained with Picada dos Tocos Carbonatite (Caçapava do Sul). Data from the Picada dos Tocos extracted from CervaAlves et al. (2017).

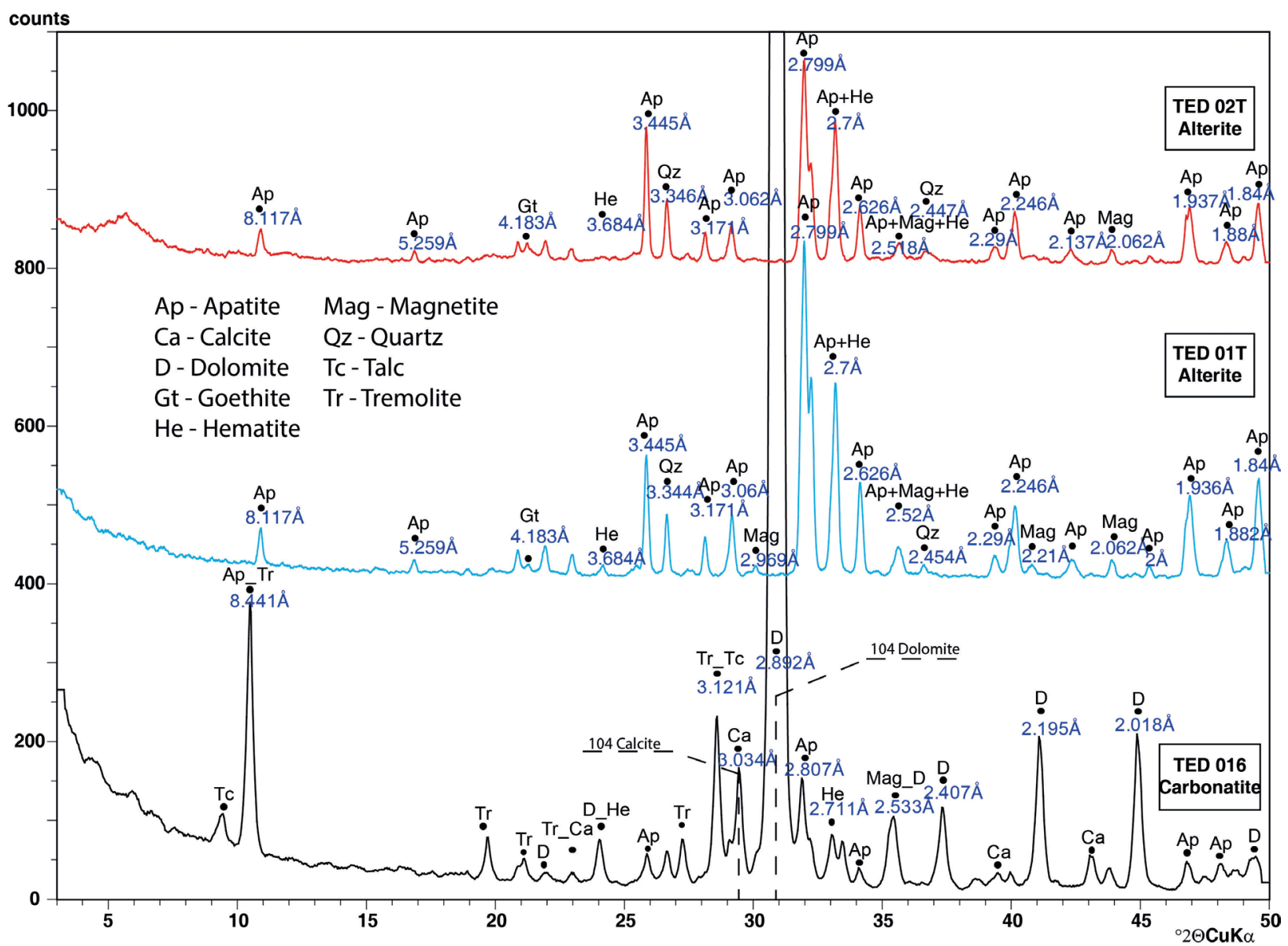

Figure 3. Diffractograms of Três Estradas Carbonatite (TEC) and its alterite (non-oriented powder samples). In the sample TED016, carbonates are identified, mainly dolomite, and, in a lesser extension talc, apatite, tremolite, magnetite and hematite. The samples of alterite TED01T and TED02T present a complete dissolution of the carbonates and a larger participation of the apatite associated with iron oxides, hydroxides (hematite and goethite), and quartz. 
natural low aluminum concentration in carbonatite (Fig. 5), this phosphate is uncommon in the TEC weathering profile.

\section{Chemical characterization of apatite types}

Considering each type of the observed apatite, from the primary one in the non-altered rock (Type 1) to apatite originated during the TEC weathering process (Types 2, 3 and 4), there are some differences not only in the morphology and mode of occurrence, but also in particularities in their chemical composition. When possible, use of EPMA determined the chemistry of different apatite types (Tab. 1). Additionally, micro Raman and FTIR were employed to elucidate the observed apatite compositions. To facilitate comparisons, the median composition ( $\mathrm{wt} \%$ ) and chemical mineral formula were calculated for each group of apatite (Tab. 2). All results are available in the Pangaea site, with the DOI number: 10.1594/PANGAEA.893030.

With weathering, primary apatite (Type 1) changed in composition and was replaced by Type 2 or altered apatite, which is characterized by an increase in $\mathrm{Ce}$ and La concentration (Figs. 9A and 9C), decrease of Sr (Fig. 9G) and progressive replacement of $\mathrm{F}$ by $\mathrm{OH}$ (Fig. 9H). Differently, types 3 and 4 of apatite (epitaxial growth and crystallites respectively) are characterized by decrease in La and Ce (Figs. 9A and 9C), strontium (Fig. 9G), phosphorus (Fig. 9F) and increase participation of $\mathrm{OH}$ that replaces $\mathrm{F}$ in Type 2 apatite (Fig. 9H). With advance of weathering, the participation of $\mathrm{F}$ in apatite composition increased that is exemplified by the highest $\mathrm{F}$ observed in Type 4 apatite (Fig. 9B). In general, when apatite Types 1 and 2 from TEC are compared with the apatite developed completely in the weathering profile (Types 3 and 4), analyses decrease in the quantity of P (Figs. 9B and 9D), La and Ce (Figs. 9A and 9C). If the analyzed concentration of
La and Ce are considered as representative of the REE behavior, apatite Types 1 and 2 retain REE and Types 3 and 4 are impoverished in these elements.

Apatite is a mineral with a general formula $\left(\mathrm{A}_{5} \mathrm{X}_{3} \mathrm{Y}_{1}\right)$, in which, ideally, $\mathrm{A}=\mathrm{Ca}^{2+} ; \mathrm{X}=\mathrm{PO}_{4}^{3-} \mathrm{Y}=\mathrm{F}$. A wide variety of substitutions are observed in every crystallographic site of the mineral. Especially in the $\mathrm{Y}$ site, $\mathrm{F}$ may be replaced by $\mathrm{Cl}$ or $\mathrm{OH}$ ions in different degrees, composing a solid solution that forms the three final members of the apatite group in three varieties, identified respectively as fluorapatite (F-Ap), chlorapatite (ClAp), and hydroxyapatite (H-Ap). Substitutions and each kind of apatite produce differences in the physical properties and mineral solubility, which significantly influence many industrial applications (Kohn et al.2002). In practice, difficulties in the determination of apatite composition are related with the analytical limitations of EPMA, especially in relation to $\mathrm{OH}$ determination (Stormer Jr. et al. 1993). These difficulties are evident in the compositional results obtained in this work by EPMA and are observed in the sum of components of each chemical analysis, which varies from the expected total around $100 \%$ to results distant from the ideal total values. It is specially observed with apatite Types 3 (epitaxial growth) and 4 (crystallites), which systematically presented totals around 93\% (Figure 9D), differently from totals obtained around $100 \%$ for apatite analyses Types 1 and 2. Most EMPA mineral analyses with total not within the expected interval from 98 to $102 \%$ are rejected. In this paper, these results were not interpreted as errors, but they were related to problems concerning the non-analyzed compounds normally found in apatite, such as $\mathrm{CO}_{3}{ }^{2-}$ and $\mathrm{OH}$. In contrast to the primary Types 1 and 2 , the apatites developed entirely in the weathering profile show a decrease in the total analyzed (Fig. 9D) and $\mathrm{P}_{2} \mathrm{O}_{5}$ concentration (Fig. 9E). This result was also observed by Toledo et al.

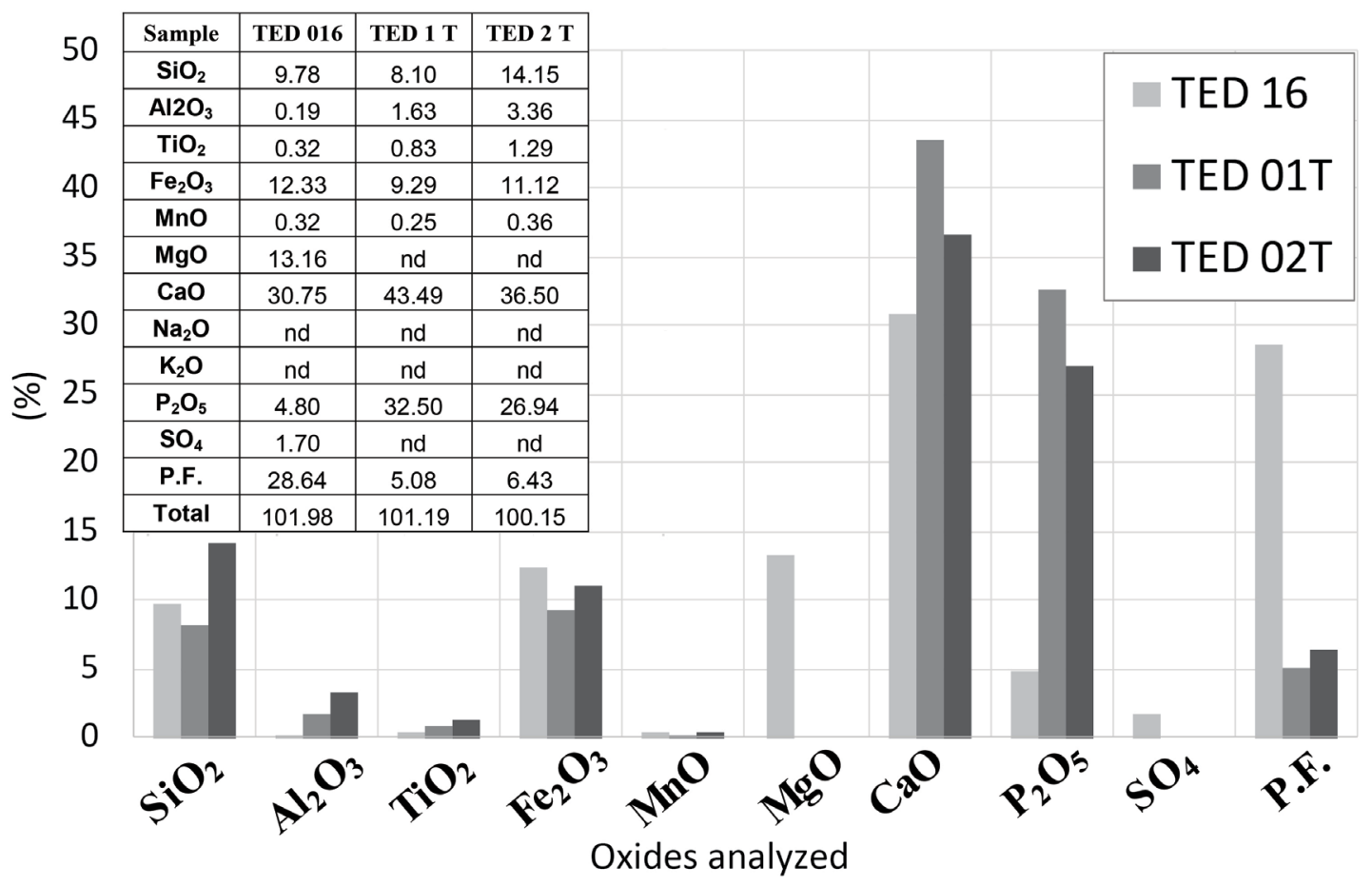

Figure 5. Concentration variation of major chemical elements (wt\%) in the unaltered sample (Três Estradas Carbonatite - TED 16) and the weathering profile (TED 01T and TED 02T) of TEC. The enrichment in phosphate is related to the apatite preservation in the weathering profile, and the drastic decrease in magnesium concentration indicates the dolomite dissolution. 

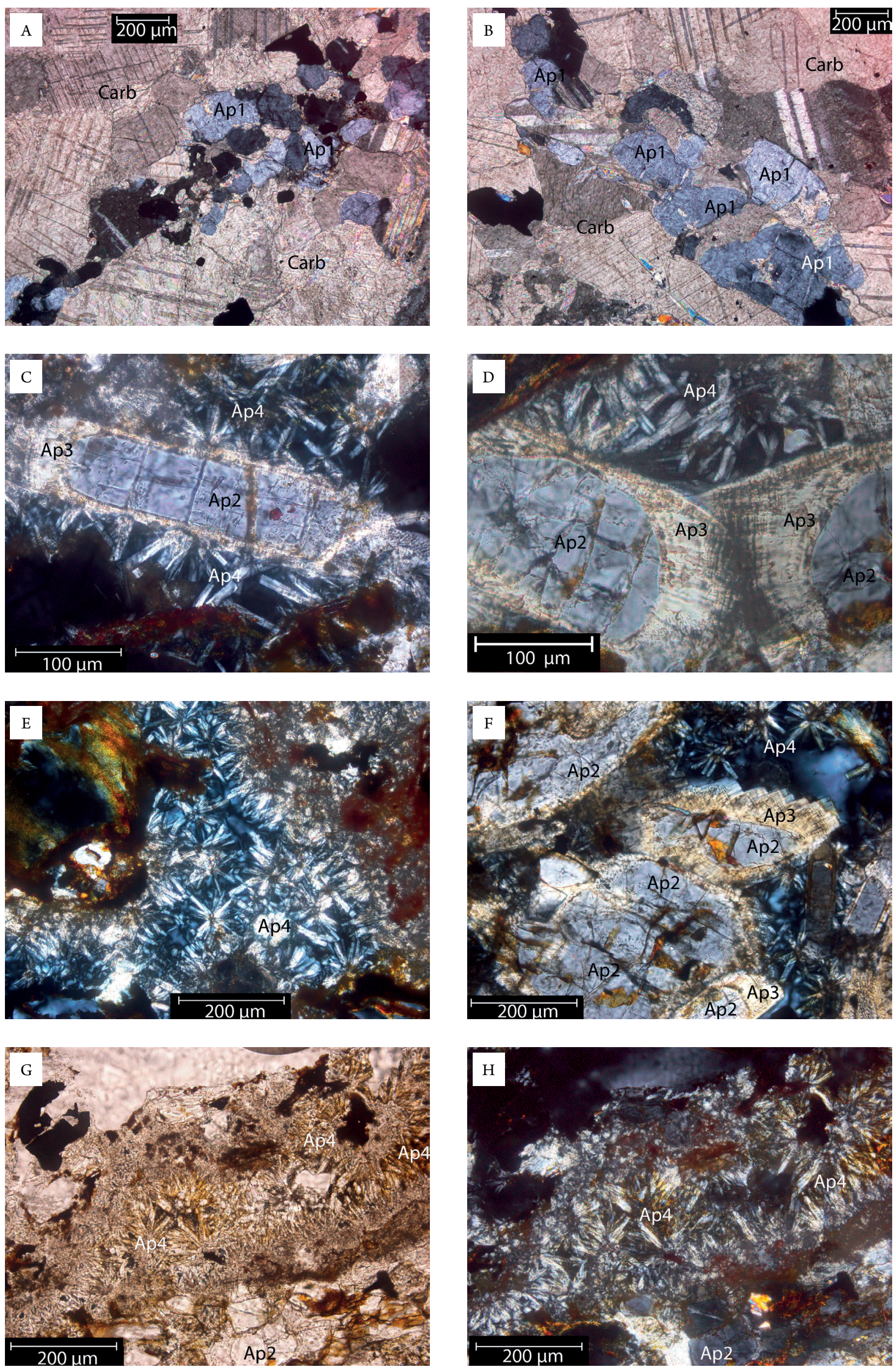

Figure 6. Images obtained by optical microscope. Images A and B exhibit type 1 apatite (Ap1), occurring concentrated in bands of the carbonatite. Images C, D, E, F, G and H illustrate the other apatite types present in the weathering samples. Type 2 apatite (Ap2) exhibits dissolution edges. The epitaxial growth (Ap3) occurs covering the type 2 apatites, forming euhedral forms. Type 4 apatite (Ap4) occurs over the preexisting apatite crystal, as well as in the form of radial aggregates (Image $\mathrm{E}$ ) and filling veins (Images $\mathrm{G}$ and $\mathrm{H}$ ). 

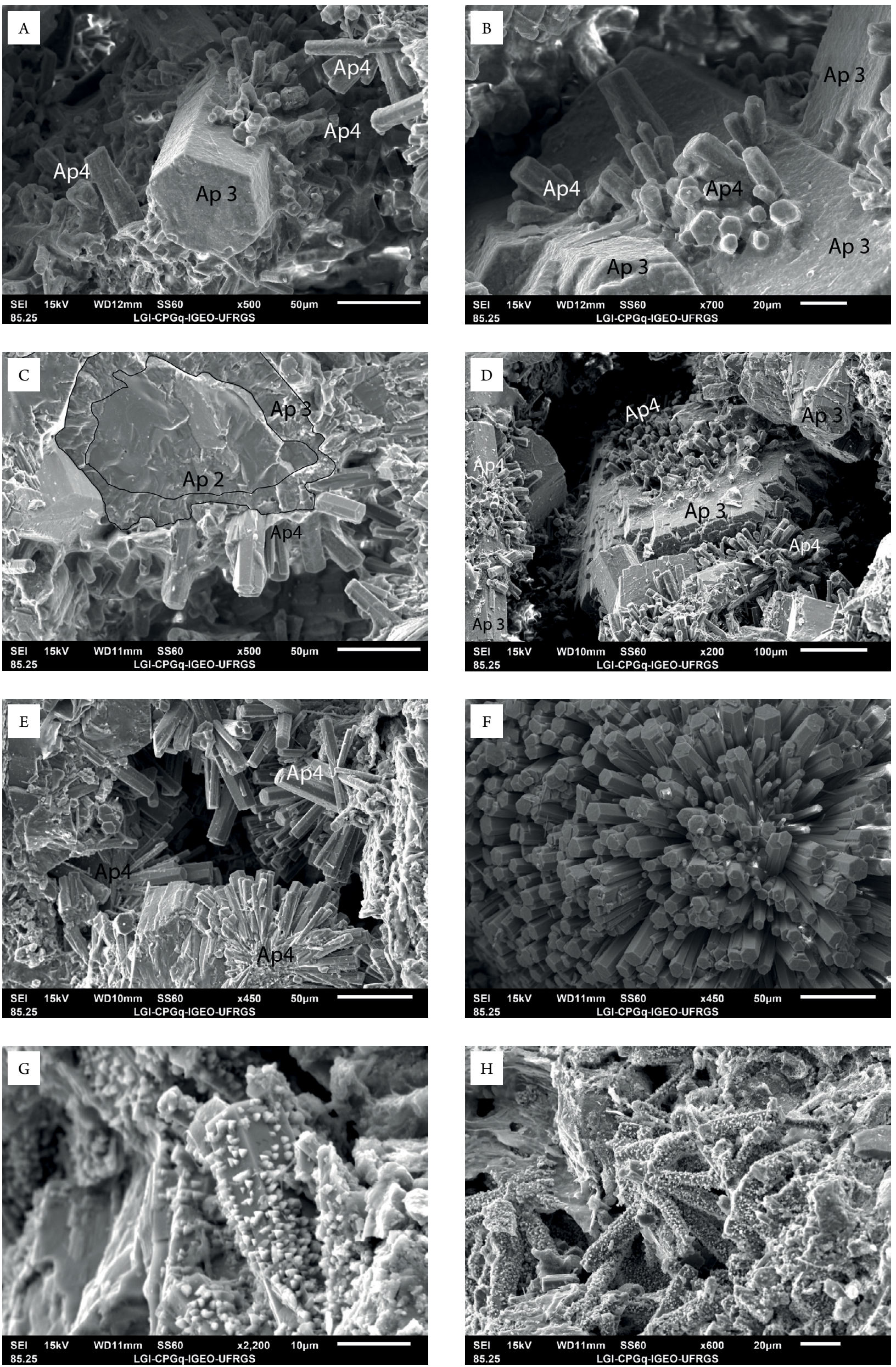

Figure 7. Secondary electron images obtained from the analysis of alterite fragments (samples TED 01T and 02T). The prismatic crystals of type 4 apatite partly cover the type 3 apatite on the images A, B, C, D and E. In Image C, it is possible to see a nucleus formed by type 2 altered apatite, covered by epitaxial growth of type 3 apatite and finally the crystallites growing in a prismatic way on the mineral surface. Image $\mathrm{F}$ shows the type 4 apatite forming a radial aggregate. Images $\mathrm{G}$ and $\mathrm{H}$ show pyramidal crystals of aluminum-phosphate associated with weathering products. 
(2004) and interpreted as $\mathrm{X}$ site $\mathrm{PO}_{4}^{3-}$ substitution by $\mathrm{CO}_{3}{ }^{2-}$ and the entrance at the $\mathrm{Y}$ site of $\mathrm{OH}$ replacing $\mathrm{F}$. To correctly evaluate these kinds of substitutions, Raman spectroscopy and FTIR techniques are the most appropriate methods (Antonakos et al.2007, Elliot 1994, Penel et al. 1998) and were implemented in this work to characterize apatites observed in TEC. The application of these techniques permitted to complement the analytical data of EPMA, improving the characterization of each apatite type.

To evaluate $\mathrm{CO}_{3}$ associated with the $\mathrm{X}$ site in the studied apatites, the technique of FTIR was used. Some types of apatites identified in the profile, such as Types 2 and 3, occur as continuous crystal (Figs. 6C, 6D and 6F), making the separation of each apatite impracticable for FTIR analysis using $\mathrm{KBr}$ pressed discs. Consequently, the obtained FTIR of these apatites is the average composition of Types 2 and 3 . Typical absorption bands of $\mathrm{CO}_{3}$ occur in the spectral interval between 1,650 and $1,300 \mathrm{~cm}^{-1}$ (Rehman \& Bonfield 1997). By the FTIR, the methodology employed for the determination of $\mathrm{CO}_{3}$ concentration was based on the work of Grunenwald et al. (2014), which used parameters like the area of the $\mathrm{PO}_{4}$ $\mathrm{v}_{3}$ and $\mathrm{v}_{1}$ infrared absorption bands and the area of the $\mathrm{CO}_{3}$ $\mathrm{v}_{3}$ band (Fig. 10). The concentration of carbonate present in the analyzed apatite was calculated as follows (Eqs. 1 and 2):

$r_{c / p}=\frac{\left[\operatorname{area~}_{3}\left(\mathrm{CO}_{3}\right)\right]}{\left[\operatorname{area~}_{1} v_{3}\left(\mathrm{PO}_{4}\right)\right]}$
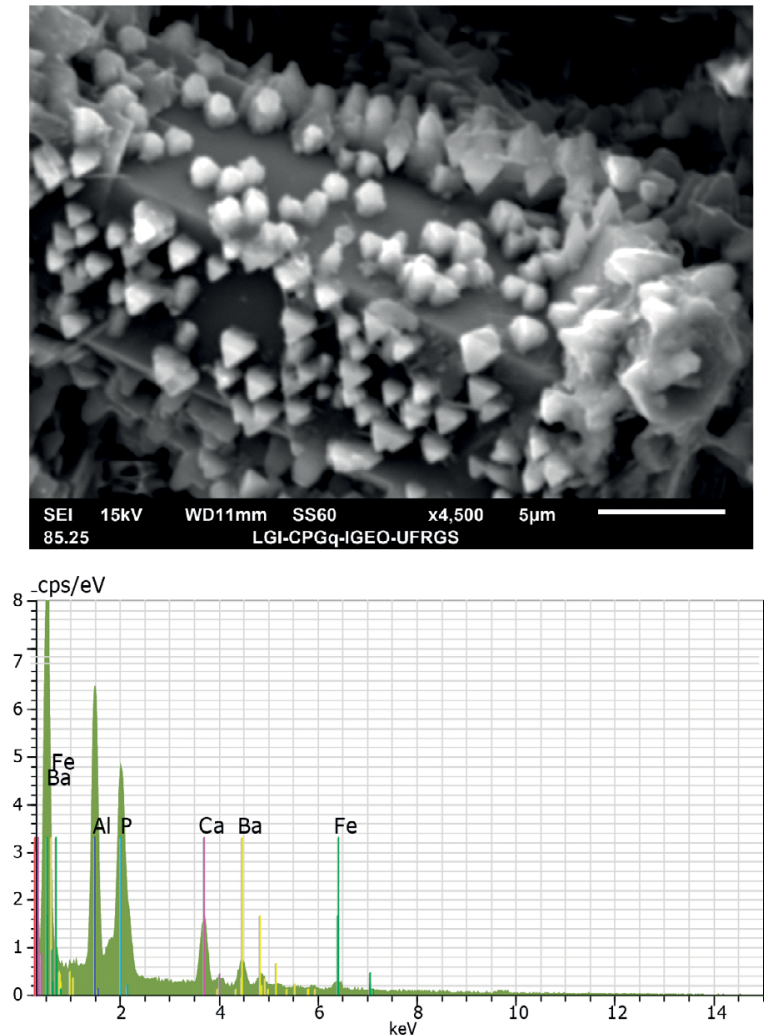

Figure 8. EDS analysis of the aluminum-phosphate with scanning electron microscope. Note that the spectrum indicates a predominant composition of aluminum and phosphorus and a minor participation of barium, iron, and calcium. $\mathrm{wt} \% \mathrm{CO}_{3}=28.62 \times \mathrm{r}_{\mathrm{c} / \mathrm{p}}+0.0843$

By applying this methodology to apatite separated from sample TED 01T (Fig. 9A and Eqs. 3 and 4):

$\left[\operatorname{area~} v_{3}\left(\mathrm{CO}_{3}\right)\right]=24.05215$

$\left[\right.$ area $\left.\mathrm{v}_{1} \mathrm{v}_{3}\left(\mathrm{PO}_{4}\right)\right]=107.25097$

$r_{c / p}=\frac{[24.05215]}{[107.25097]}=0.2243$

$\mathrm{wt} \% \mathrm{CO}_{3}=28.62 \times 0.2243+0.0843$

$\mathrm{wt} \% \mathrm{CO}_{3}=6.5 \%$

Applying this methodology to apatite separated from sample TED02T (Fig. 9B and Eqs. 5 and 6):

$$
\begin{aligned}
& {\left[\operatorname{area~}_{3}\left(\mathrm{CO}_{3}\right)\right]=27.42087} \\
& {\left[\operatorname{area~}_{1} \mathrm{v}_{3}\left(\mathrm{PO}_{4}\right)\right]=117.54013} \\
& \mathrm{r}_{\mathrm{c} / \mathrm{p}}=\frac{[27.42087]}{[117.54013]}
\end{aligned}
$$

$\mathrm{wt} \% \mathrm{CO}_{3}=28.62 \times 0.2333+0.0843$

$\mathrm{wt} \% \mathrm{CO}_{3}=6.7 \%$

Apatite originated from the weathering TEC profile has a different behavior from the primary type (Type 1). Types 3 and 4 have significant participation of $\mathrm{CO}_{3}$ in their composition, which is not detected in the $\mathrm{X}$ site of apatite Type 1 and $\mathrm{CO}_{3}$ group.

Additionally, $\mathrm{OH}$ participation in the $\mathrm{Y}$ apatite site is not determined by EPMA analyses; therefore, a normal procedure is the quantification of this group through stoichiometric calculation, whose results are sometimes questionable. In this work, beyond stoichiometric calculation, the evaluation of $\mathrm{OH}$ group was made directly using the micro-Raman spectroscopy facilities. Each apatite type was separated and fixed in mounts and subjected to a micro Raman beam that covers an area with a diameter of approximately $3 \mu \mathrm{m}$. Considering beam diameter, apatite Type 4 (crystallites) has small size resulting in unclear Raman measurements, showing an influence of mount resin making the obtained spectra useless. The $\mathrm{OH}$ group was identified in primary apatite (Type 1) as well as in altered ones (Type 2), while epitaxial apatite (Type 3) has no indication of this group (Fig. 11).

\section{DISCUSSION}

In this paper, the described apatite has morphological and chemical differences in addition to distinct modes of occurrence, considering the carbonatite and evolved weathering products. 
Braz. J. Geol. (2019), 49(2): e20180092

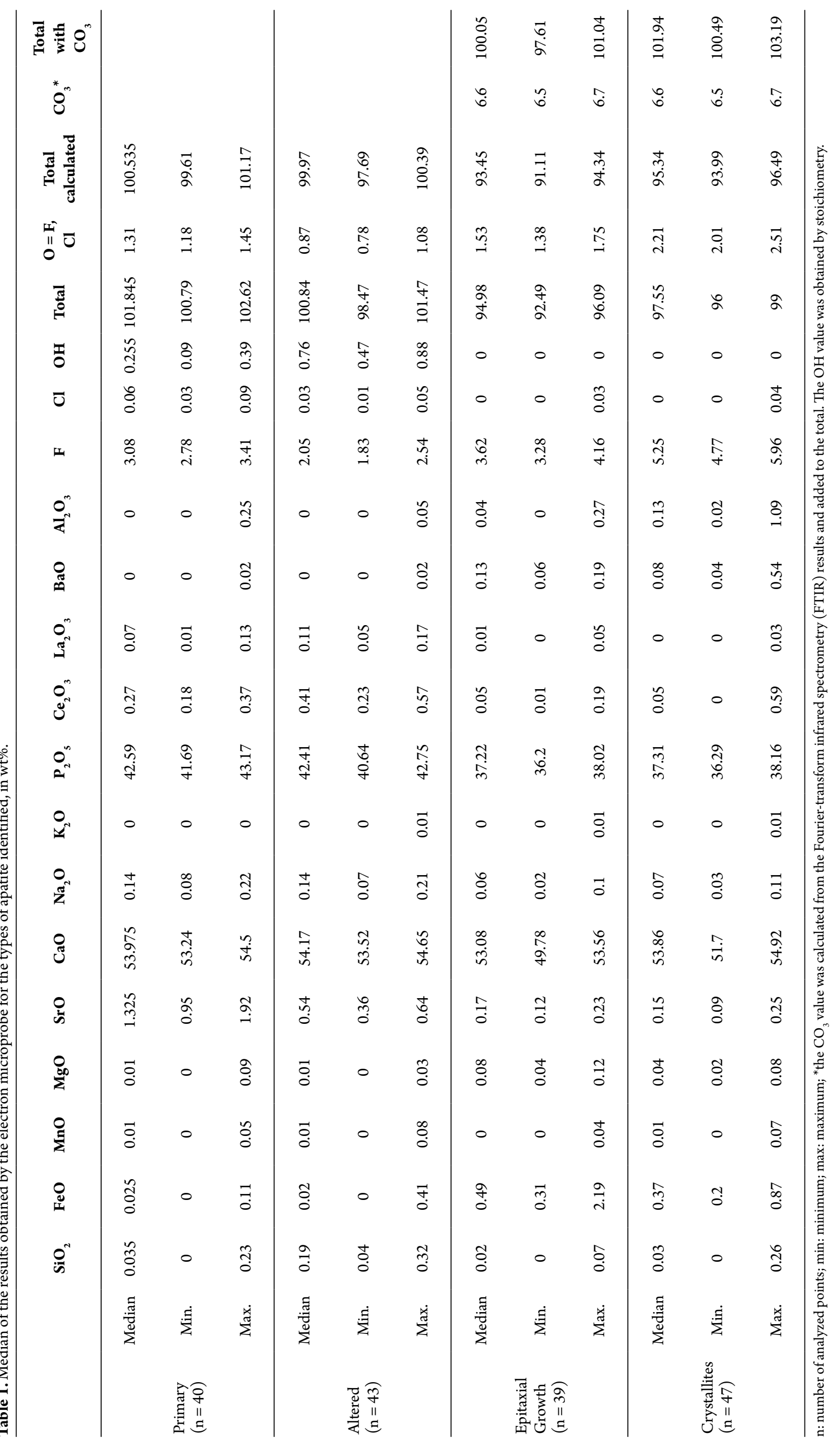




\section{Type 1: primary apatite}

Primary apatites of Type 1 are equigranularmineralswithsubhedral shape, without visiblezonation and often with fractures. Crystals occur concentrated in bands and associated with opaque minerals (magnetite, hematite and sulfides, especially pyrite) of the unaltered TEC.A suggested chemical formula is expressed in Equation 7:

$\left(\mathrm{Ca}_{9.73} \mathrm{Na}_{0.05} \mathrm{Ce}_{0.02} \mathrm{Sr}_{0.13}\right)\left[\left(\mathrm{PO}_{3}\right)_{6.07}\left(\mathrm{SiO}_{4}\right)_{0.01}\right]\left(\mathrm{Cl}_{0.02} \mathrm{~F}_{1.64} \mathrm{OH}_{0.29}\right)$

$\mathrm{Y}$ site is dominated by $\mathrm{F}$ and $\mathrm{OH}$ that allow the mineral to be classified as fluor-hydroxyapatite. In the cationic site A, Ca predominates, admitting substitutions for $\mathrm{Na}, \mathrm{Ce}$, and $\mathrm{Sr}$. Due to Ce, the presence of elements from the REE group is inferred in this type of apatite, although the entire REE group was not analyzed in this work. In the $\mathrm{X}$ mineral site, the $\mathrm{PO}^{3-}$ group dominates and $\mathrm{CO}_{3}$ was not detected.

\section{Type 2: altered apatite}

The transition from rock to weathered carbonatite is sharp and apatite Type 1 is absent from weathered samples. The modified early apatite (Type 1) found in weathering profile was denominated altered apatite (Type 2), which maintains a composition like apatite Type 1 . However, altered apatite (Type 2) when compared with Type 1 has significant differences and its morphology is marked by rounded mineral edges (Fig. 6). The rounded edges indicate activity of weathering processes that promoted partial mineral dissolution in a similar mode as observed in Catalão I carbonatite (Toledo et al. 2004). With EPMA chemical analyses, the mineral formula is similar to apatite Type 1 and is classified as fluor-hydroxyapatite (Eq. 8):

$\mathrm{Ca}_{9.88} \mathrm{Na}_{0.05} \mathrm{La}_{0.01} \mathrm{Ce}_{0.03} \mathrm{Sr}_{0.05}\left[\left(\mathrm{PO}_{3}\right)_{6.11}\left(\mathrm{SiO}_{4}\right)_{0.03}\right] \mathrm{Cl}_{0.01} \mathrm{~F}_{1.10} \mathrm{OH}_{0.30}(8)$
Additionally, $\mathrm{OH}$ substitution of $\mathrm{F}$ in the mineral site $\mathrm{Y}$ increases when compared to Type 1, which denotes a compositional trend with weathering (Fig. 9). In relation to Type 1 , the mineral site A decreases in $\mathrm{Sr}$ due to relative gain in $\mathrm{Ce}$ that is not mobilized at this weathering stage. As type 1 , the mineral site $\mathrm{X}$ is occupied by $\mathrm{PO}_{3}$, and $\mathrm{CO}_{3}$ was not detected.

\section{Type 3: epitaxial growth}

Apatite Type 3 is a generation of apatite developed in TEC weathering environment. This apatite occurs as a precipitate in the form of epitaxial growth (Fig. 6D), following the crystallographic structure of altered apatite (Type 2), occupying the crystal core. The most probably chemical formula is expressed in Equation 9:

$\mathrm{Ca}_{9.85} \mathrm{Na}_{0.02} \mathrm{Mg}_{0.02} \mathrm{Fe}_{0.07} \mathrm{Ba}_{0.01} \mathrm{Al}_{0.01} \mathrm{Sr}_{0.02}\left[\left(\mathrm{PO}_{3}\right)_{548}\left(\mathrm{CO}_{3}\right)_{1.14}\right] \mathrm{F}_{2.00}$

In apatite Type 3, the mineral site $\mathrm{Y}$ has $\mathrm{F}$. In mineral site A, Ca predominates partially replaced by $\mathrm{Na}, \mathrm{Mg}, \mathrm{Fe}, \mathrm{Ba} \mathrm{Al}$ and $\mathrm{Sr}$, with no piece of evidence of Ce or La. This denotes that the REE group is not retained in apatite generated by carbonatite weathering. This piece of evidence must be investigated more closely due to similarity with phosphate deposits, in which ore with potentiality to be exploited is in the weathering mantle. In site $\mathrm{X}$, there is a significant participation of $\mathrm{CO}_{3}$ in substitution to $\mathrm{PO}_{3}$. These characteristics allow to classify apatite Type 3 as carbonate fluorapatite (Deer et al. 1992, Straaten 2002).

\section{Type 4: crystallites}

The youngest type of apatite occurs as crystallites, with dimensions around $50 \mu \mathrm{m}$, and due to their small size, they are visualized with some difficulty by optical microscopy (Fig. 6). However, the type is better detailed with SEM (Fig. 7).

Table 2. Chemical formula calculated for the occurring apatites, using the results from electron microprobe and Fourier-transform infrared spectrometry (FTIR) (number of $\mathrm{O}+\mathrm{F}+\mathrm{OH}+\mathrm{Cl}=26$ used for the primary and changed apatite. For the epitaxial growth and crystallites, the chemical formula was calculated using the basis of 10 cations).

\begin{tabular}{|c|c|c|c|c|c|c|c|c|c|c|c|c|c|c|c|c|c|}
\hline & & $\mathbf{C a}$ & $\mathbf{N a}$ & Mn & Mg & $\mathbf{F e}$ & La & $\mathrm{Ce}$ & $\mathbf{B a}$ & Al & $\mathbf{S r}$ & $\mathbf{P}$ & C & $\mathbf{S i}$ & Cl & $\mathbf{F}$ & $\mathbf{O H}$ \\
\hline \multirow{3}{*}{$\begin{array}{l}\text { Primary } \\
(\mathrm{n}=41)\end{array}$} & Median & 9.70 & 0.05 & 0.00 & 0.00 & 0.00 & 0.00 & 0.02 & 0.00 & 0.00 & 0.13 & 6.05 & 0.00 & 0.01 & 0.02 & 1.63 & 0.29 \\
\hline & Min & 9.60 & 0.03 & 0.00 & 0.00 & 0.00 & 0.00 & 0.01 & 0.00 & 0.00 & 0.09 & 5.99 & 0.00 & 0.00 & 0.01 & 1.49 & 0.10 \\
\hline & Max & 9.80 & 0.07 & 0.01 & 0.02 & 0.02 & 0.01 & 0.02 & 0.00 & 0.05 & 0.19 & 6.09 & 0.00 & 0.04 & 0.03 & 1.81 & 0.44 \\
\hline \multirow{3}{*}{$\begin{array}{l}\text { Changed ( } \mathrm{n} \\
=44)\end{array}$} & Median & 9.75 & 0.05 & 0.00 & 0.00 & 0.00 & 0.01 & 0.03 & 0.00 & 0.00 & 0.05 & 6.03 & 0.00 & 0.03 & 0.01 & 1.10 & 0.85 \\
\hline & Min & 9.66 & 0.02 & 0.00 & 0.00 & 0.00 & 0.00 & 0.01 & 0.00 & 0.00 & 0.04 & 5.97 & 0.00 & 0.01 & 0.00 & 0.97 & 0.54 \\
\hline & Max & 9.94 & 0.07 & 0.01 & 0.01 & 0.06 & 0.01 & 0.04 & 0.00 & 0.01 & 0.06 & 6.07 & 0.00 & 0.05 & 0.01 & 1.39 & 0.99 \\
\hline \multirow{3}{*}{$\begin{array}{l}\text { Epitaxial } \\
\text { growth } \\
(n=40)\end{array}$} & Median & 9.85 & 0.02 & 0.00 & 0.02 & 0.07 & 0.00 & 0.00 & 0.01 & 0.01 & 0.02 & 5.48 & 1.14 & 0.00 & 0.00 & 2.00 & 0.00 \\
\hline & Min & 9.52 & 0.01 & 0.00 & 0.01 & 0.04 & 0.00 & 0.00 & 0.00 & 0.00 & 0.01 & 5.32 & 1.14 & 0.00 & 0.00 & 1.81 & 0.00 \\
\hline & Max & 9.89 & 0.03 & 0.01 & 0.03 & 0.33 & 0.00 & 0.01 & 0.01 & 0.06 & 0.02 & 5.60 & 1.18 & 0.01 & 0.01 & 2.27 & 0.00 \\
\hline \multirow{3}{*}{$\begin{array}{l}\text { Crystallites } \\
(n=48)\end{array}$} & Median & 9.86 & 0.02 & 0.00 & 0.01 & 0.05 & 0.00 & 0.00 & 0.01 & 0.03 & 0.01 & 5.39 & 1.13 & 0.01 & 0.00 & 2.84 & 0.00 \\
\hline & Min & 9.59 & 0.01 & 0.00 & 0.01 & 0.03 & 0.00 & 0.00 & 0.00 & 0.00 & 0.01 & 5.21 & 1.11 & 0.00 & 0.00 & 2.57 & 0.00 \\
\hline & Max & 9.91 & 0.04 & 0.01 & 0.02 & 0.12 & 0.00 & 0.04 & 0.04 & 0.22 & 0.02 & 5.56 & 1.16 & 0.04 & 0.01 & 3.27 & 0.00 \\
\hline
\end{tabular}

Min: minimum; max: maximum. 
The Type 4 mode of occurrence suggests an origin influenced by high nucleation rate, favoring the formation of small crystals and causing the interruption of epitaxial growth (Type 3 ). Crystallites are developed late in the weathering profile and occurs where there is room for growth. Type 4 fills cavities generated by dissolved minerals such as carbonates, fringes above other minerals, radial aggregates up to $100 \mu \mathrm{m}$ and also filling
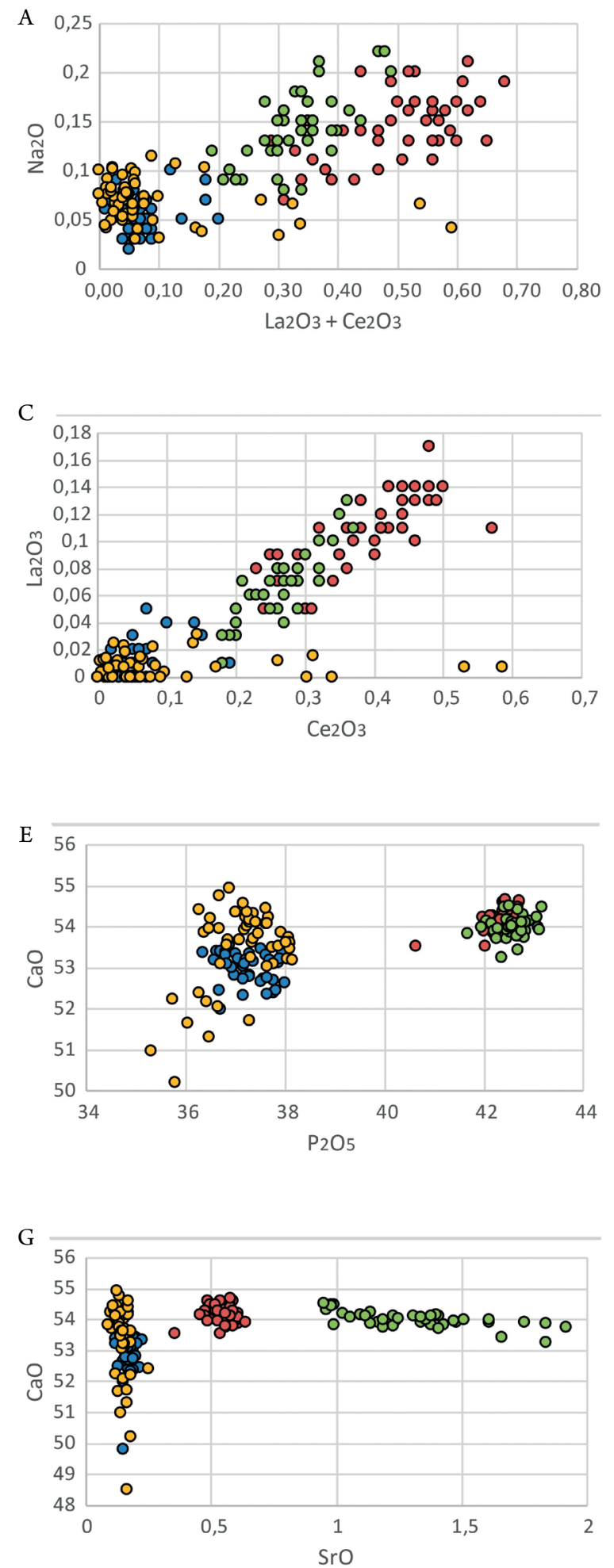

oPrimary (Type 1) oAltered (Type 2) veins, as observed by optical microscope and SEM (Figs. 6E, 6G, 6H and 7). With EMPA chemical analyses, we elaborated the following formula, expressed in Equation 10:

$\mathrm{Ca}_{9.86} \mathrm{Na}_{0.02} \mathrm{Mg}_{0.01} \mathrm{Fe}_{0.05} \mathrm{Ba}_{0.01} \mathrm{Al}_{0.03} \mathrm{Sr}_{0.01}$ $\left[\left(\mathrm{PO}_{3}\right)_{5.39}\left(\mathrm{CO}_{3}\right)_{1.13} \mathrm{Si}_{0.01}\right] \mathrm{F}_{2.84}$
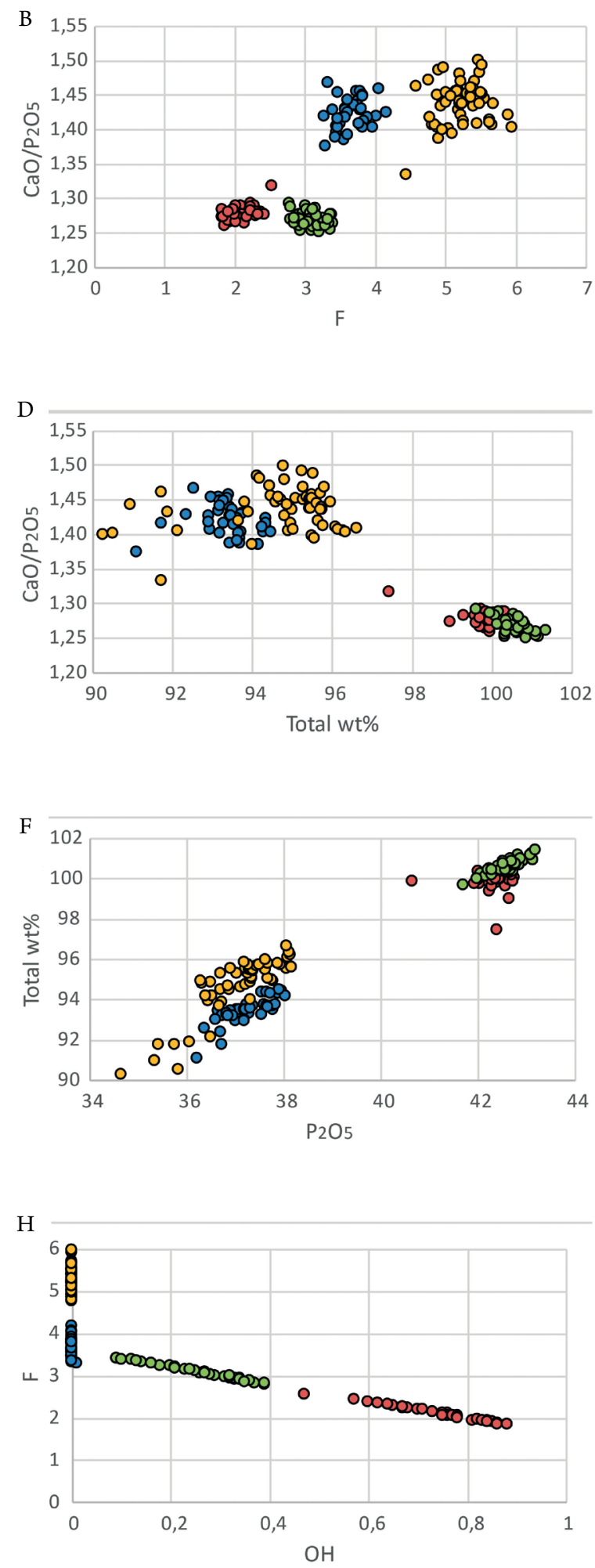

oCristallites (Type 4)

Figure 9. Behavior of the main chemical elements in the different types of apatite identified in Três Estradas Carbonatite (TEC). Results obtained from EPMA analysis. 
As in type 3, the $\mathrm{Y}$ site is entirely occupied by $\mathrm{F}$. The A site is dominated by $\mathrm{Ca}$, partially replaced by $\mathrm{Na}, \mathrm{Mg}, \mathrm{Fe}, \mathrm{Ba}, \mathrm{Al}$ and Sr. Similar to Type 3 apatite, Ce and La were not detected, suggesting weak participation of REE group. In the apatite $\mathrm{X}$ site, there is a significant participation of $\mathrm{CO}_{3}$ replacing $\mathrm{PO}_{3}$ that indicates environment of formation with high $\mathrm{CO}_{2}$ fugacity. Compositionally, apatite Type 4 is similar to Type 3 and was classified as carbonate fluorapatite (Deer et al. 1992, Straaten 2002).

\section{Aluminum-phosphates}

Identification of aluminum-phosphate minerals occurred punctually in the weathering profile and seems an uncommon phase in TEC. They are small crystals with a bipyramidal habit and size less than $3 \mu \mathrm{m}$ (Figs. 7G, 7H and 8). From SEM-EDS analysis, elements such as $\mathrm{Al}, \mathrm{P}, \mathrm{Ca}$ and $\mathrm{Ba}$ are associated with this phase (Fig. 8). The presence of Ca suggests minerals of the crandallite group (Schwab et al. 1989, Toledo et al. 2002), which are relatively common in weathering profiles over phosphatic rocks.

\section{Weathering Apatites}
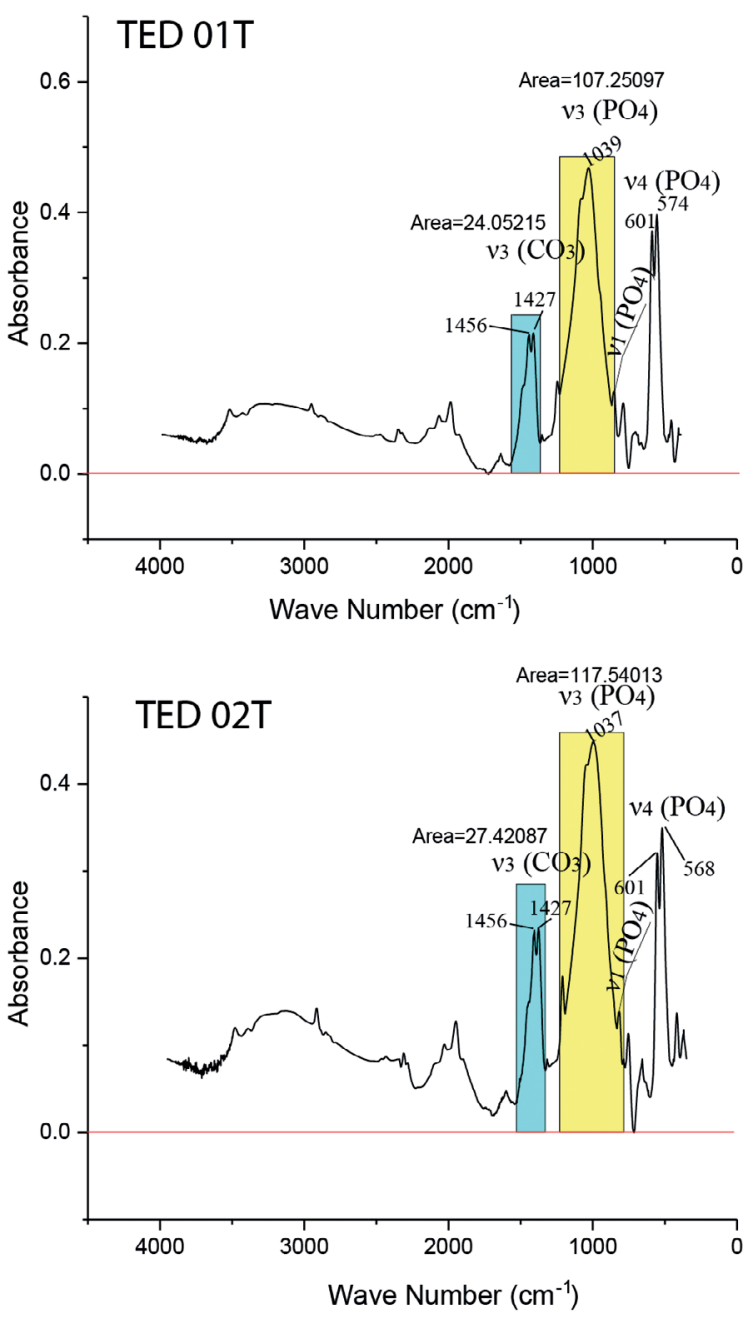

Figure 10. FTIR spectra obtained in the region between 4000 and $400 \mathrm{~cm}^{-1}$ on the weathering apatites of the samples TED01T and TED02T. The absorption bands $\mathrm{v}_{1}, \mathrm{v}_{3}$ of the $\mathrm{PO}_{4}, 3-$ and $\mathrm{v}_{3}$ of the $\mathrm{CO}_{3}$, 2- were used for the determination of the parameters in formulas 1 and 2 (Grunenwald et al., 2014).

\section{Weathering development in TEC}

Apatite types identified especially in the weathering mantle of TEC emphasizes the complexity of supergenic alteration, probably with multistages and a long process between carbonatite exposition and phosphate remobilization. Results show that phosphorus was less mobilized in the weathering profile and remained preferentially in the profile as apatite. Observations with XRD complemented by microscopy (Figs. 3 and 6) confirm the high potential to weathering of TEC and good water circulation and percolation in weathering profile, favoring carbonate dissolution (decrease in loss of ignition and $\mathrm{MgO}-$ Fig. 5). Some sulfides present in the carbonatite probably oxidized and were lixiviated (Fig. 5). Chemically, Ca content increases with weathering and is related to apatite relative enrichment (Fig. 5). TEC behavior with weathering has similarities with processes described in other carbonatites exposed to tropical and subtropical climate, such as the Juquiá carbonatite (Walter et al. 1995) and the Catalão I carbonatite complex (Oliveira \& Imbernon 1998, Toledo et al. 2004).

The alteration and dissolution process of carbonate sulfide minerals create an environment characterized by lower pH (Altschuler 1973, Neto 1991). Considering the initial step of carbonatite weathering (Fig. 12), solutions have a tendency to be acid destabilizing primary apatite (Type 1). This condition promotes dissolution of primary apatite marked by irregularities and rounded borders (Figs. $6 \mathrm{C}, 6 \mathrm{D}$ and $6 \mathrm{~F}$ ), lixiviation of $\mathrm{F}$ and $\mathrm{Sr}$ and relative enrichments in $\mathrm{OH}, \mathrm{Ce}$ and $\mathrm{La}$ (Tabs. 1 and 2, Fig. 9). In the initial weathering, carbonates rapidly disappear as observed in XRD (Fig. 3), and apatite dissolution is incomplete. It indicates progressive change in $\mathrm{pH}$ from acid in direction to neutral or slowly alkaline. The increase in $\mathrm{pH}$ associated with high phosphorous activity in the weathering profile promotes the formation of new apatite (Type 3 ) crystalizing as epitaxial growth that covers the altered apatite Type 2. Progressively, saturation of porous solutions with phosphorous and calcium creates ideal conditions to increase the rate of apatite nucleation (Walter et al. 1995), favoring microcrystal formation (apatite Type 4). The process of carbonatite weathering and stability or dissolution of apatite and rock minerals is controlled by water availability to reactions on the profile. The variability in the water amount can be explained by factors such as climate changes alternating humid and dry periods associated with surface relief disposition. In similar surface relief condition, arid periods favor the increase in ionic saturation of solutions, alkalinity level, and apatite nucleation (Fig. 12).

\section{CONCLUSIONS}

The combination of analytical techniques used in this paper permits the determination of four types of apatites associated with TEC. Modes of occurrence of each apatite type also represent a successive sequence of different generations that evolve from the primary apatite (Type 1) observed on the rock to weathering types (Types 2, 3 and 4). 
Primary apatite (Type 1) of igneous/metamorphic origin was a result of magma crystallization with small modifications due to deformation and metamorphism. This apatite occurs in the non-weathered carbonatite and is classified as fluor-hydroxyapatite, with some substitution of $\mathrm{Ca}$ in the structural position $\mathrm{A}$ by $\mathrm{Na}$, Ce and $\mathrm{Sr}$.

Despite mineral similarity with primary apatite (Type 1), apatite Type 2 was modified by initial weathering, marking the mineral by dissolution features, such as rounded borders and irregular edges. Apatite Type 2 holds a composition to be classified as fluor-hydroxyapatite with a decrease in $\mathrm{Sr}$ and relative enrichment in $\mathrm{Ce}$, which is not mobilized in this weathering stage (Fig. 9). OH increases its participation by $\mathrm{F}$ substitution in the mineral site $\mathrm{Y} ; \mathrm{CO}_{3}$ was not detected in apatite site $\mathrm{X}$.
The particularities observed on the altered apatite (Type 2) characterize a process of apatite destabilization. Gradually, the percolating solutions along the weathering profile become more saturated and stop the early trend to apatite dissolution, reverting to a new event of apatite growth (Type 3). Difficulties in water circulation or a supply decrease due to climate changes are possibilities that must be considered for these modifications. Epitaxial apatite Type 3 growth over remaining crystals of apatite Type 2 are distinguished by certain characteristics, such as the occupation of mineral $\mathrm{X}$ site by $\mathrm{CO}_{3}$, which is probably because of high dissolved $\mathrm{CO}_{2}$ in the solution. The observed partial substitution of $\mathrm{PO}_{3}$ by $\mathrm{CO}_{3}$ group individualizes Type 3 apatite as carbonate-fluorapatite or francolite type. The increasing tendency of ionic concentration of
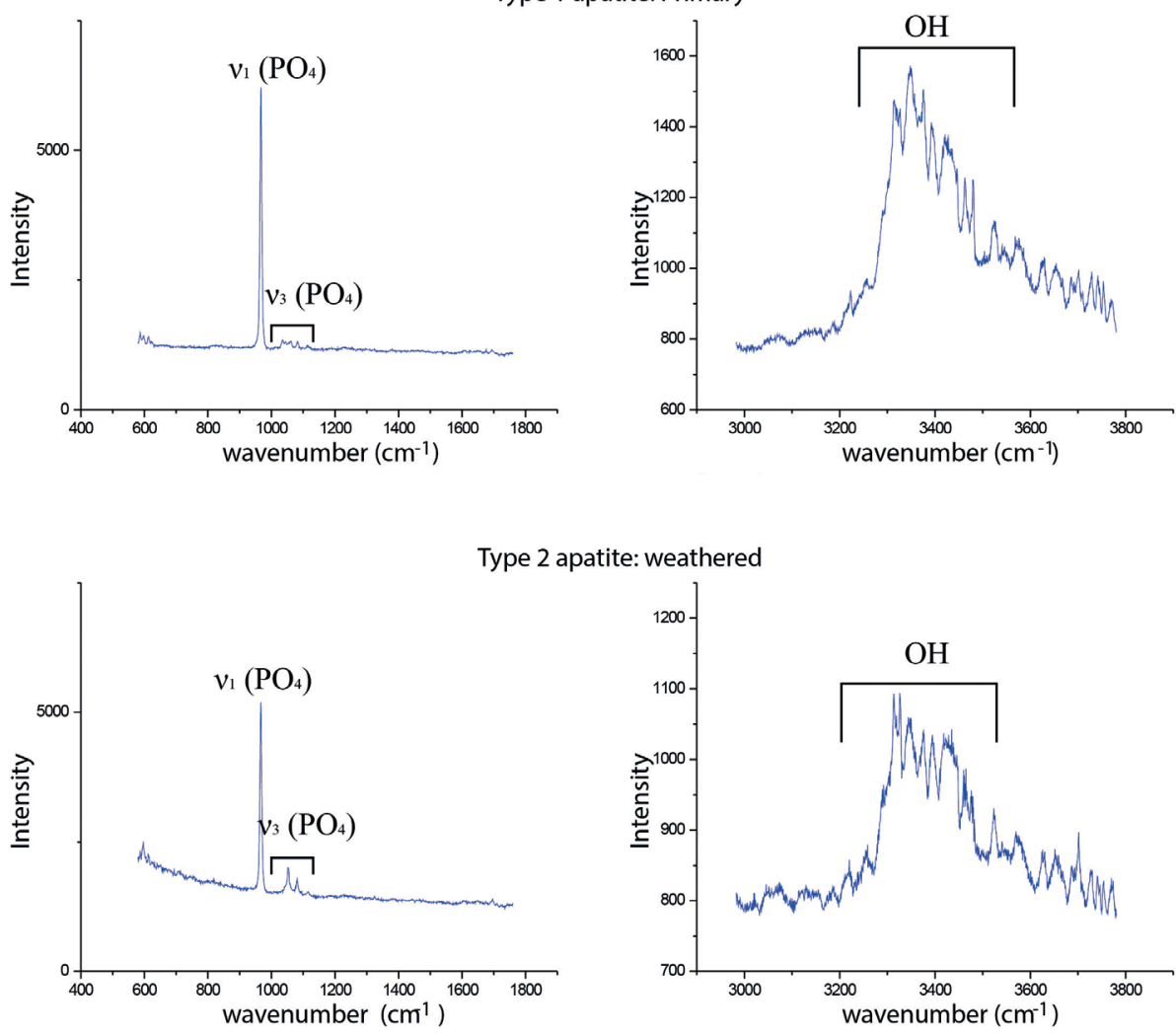

Type 3 apatite: Epitaxial Growth
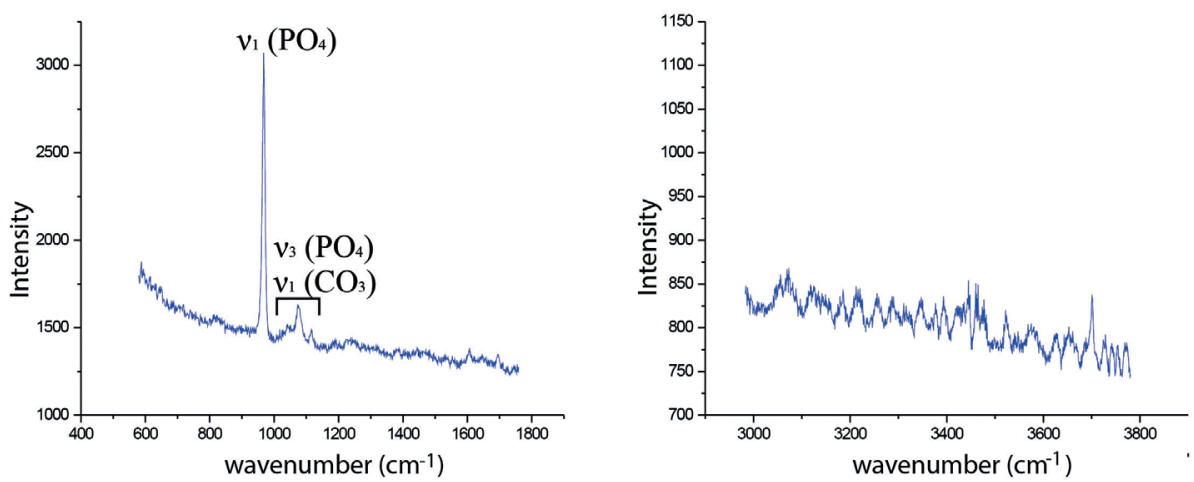

Figure 11. Micro-Raman Spectra of the different types of apatites (Types 1,2 and 3) of the region between 400 and $1800 \mathrm{~cm}^{-1}$, where the $\mathrm{PO}_{4}$ group and $\mathrm{CO}_{3}$ lines can be identified, and the region between 3000 and $3800 \mathrm{~cm}^{-1}$ where the $\mathrm{OH}$ group occurs can also be found. The $\mathrm{OH}$ group is present in the primary apatite (Type 1) and in the weathered apatite (Type 2), but it was not detected in the Type 3 apatite (epitaxial growth in a weathering environment), whereas the $\mathrm{CO}_{3}$ group is significant only in the supergenic apatites. 


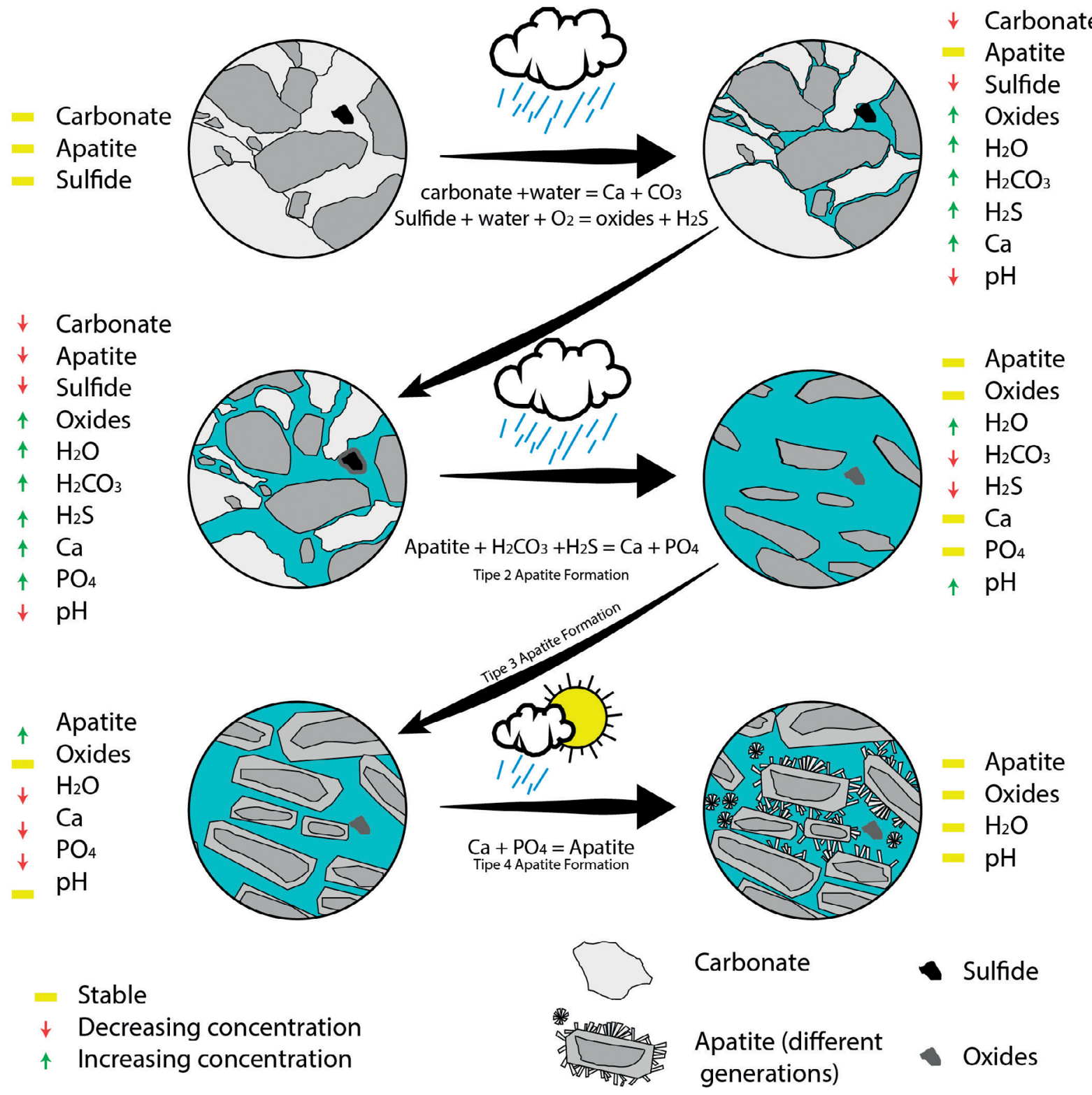

Figure 12. Schematic model proposed for the weathering process observed in Três Estradas Carbonatite (TEC) and for the formation of apatite generations identified along the profile. The exposition of the TEC to weathering action resulted, after the dissolution from the carbonates and the oxidation of associated sulfides, in a progressive decrease in $\mathrm{pH}$, consequently destabilizing the primary apatite (Type 1). Posteriorly, climate changes over the time caused the establishment of variations in the level of water and oscillation between hydromorphic and leachers conditions, which probably influenced the concentration of ions in solution and the formation of the different apatite generations identified in the paper.

percolating solution is maintained along the profile, and the resulting oversaturated solution favors the formation of apatite Type 4 in all porous spaces or cavities, regardless of the existence of a previous apatite substrate (Type 3). Differently from Types 1 and 2, compositionally, apatite Type 4 continues to be a carbonate fluorapatite or francolite as observed for apatite Type 3 .

The conditions that promoted the TEC weathering were favorable to the formation and development of phosphate minerals, particularly of the apatite group. Mineralogical investigation shows that aluminum phosphates minerals frequently observed in weathering products are rare in TEC profile. Such rarity is expected to be related to peculiar rock composition, practically depleted in aluminum, considered to be a fundamental factor for the development of aluminum phosphates (Vieillard et al. 1979). The uncommon occurrence of aluminum-phosphates was observed over a substrate of apatite crystallites (Figs. 7G, 7H and 8), reinforcing the late origin and influence of an external source of aluminum, which is probably derived from associated surrounding rocks (SMCGC) as explained in the case of some quartz identified by XRD (Fig. 3 ) in weathered carbonatite.

The apatite types studied in the TEC weathering profile indicate a multi-step generation in different conditions, influenced by changes in landscape and climate that affected physical-chemical properties of percolating solutions. The multi-generations of apatite observed required considerable time for their formation, involving periods dominated by dissolution or apatite crystallization, which is more suitable to be preserved in terrains with a long tectonic history of stability, such as the 
Southern Rio-Grandense Shield, with a low erosion rate that allows the preservation of thick profiles, especially on rocks with a high weathering rate, such as carbonatites. All these factors contribute to raising the prospect interest of TEC region for the development of an exploitable deposit of phosphate. Results obtained in this paper on apatite makes evident the existence of important chemical variability with a high possibility to promote different mineral properties, which should be considered to optimize beneficial processes in future projects of utilization of TEC phosphate accumulation.

\section{ACKNOWLEDGEMENTS}

The authors are grateful to Águia Resources Limited for the support to this project and to Centro de Estudos em Petrologia e Geoquímica of Instituto de Geociências Universidade Federal do Rio Grande do Sul (UFRGS). Also, to Naira Maria Balzaretti and Laboratório de Altas Pressões e Materiais Avançados of Instituto de Física - UFRGS for the cooperation in the micro-Raman spectrometry analyses. We wish to particularly thank Léo Afraneo Hartmann for his help and comments.

\section{ARTICLE INFORMATION}

Manuscript ID: 20180092. Received on: 08/21/2018. Approved on: 04/29/2019.

H.M.A. did all the sample preparation and analysis, interpreted the data and wrote the full manuscript and images. The author N. D. supervised the first author and helped with the whole manuscript and images. M. V. D. R. contributed to the optical petrography with identification of different apatite phase generations and assistance in the writing and revision of the manuscript. R. R. R. provided help with Figures 1 and 2 and revision of the manuscript. A. R. N. contributed to mining company data and samples from Águia Fertilizantes S. A. K. M. V. R. provided data interpretation from EPMA, and helped with Figure 1 and the manuscript revision.

Competing interests: The authors declare no competing interests.

\section{REFERENCES}

Águia Resources Limited. 2015. Águia Provides Drill Program Update for Três Estradas Project, Brazil. Brazil, Águia Resources Limited. Available from: <https://www.asx.com.au/asxpdf/20150109/pdf/42vxl959mp2pn6.pdf>. Acesssed on: October 11, 2017.

Águia Resourses Limited. 2017. Drilling of Southeast Zone At Três Estradas Continues to Return Impactful Results. Brazil, Águia Resources Limited. Available from: <https://www.asx.com.au/ asxpdf $/ 20170508 / \mathrm{pdf} / 43 \mathrm{j} 38 \mathrm{xfm} 2 \mathrm{r} 5 \mathrm{gq0}$.pdf $>$. Accessed on: January $10,2018$.

Almeida F.F.M. 1967. Origem e evolução da Plataforma Brasileira. Boletim da Divisão de Geologia e Mineralogia. Rio de Janeiro, Departamento Nacional de Produção Mineral, 36 p.

Almeida F.F.M., Hasui Y., Brito Neves B.B., Fuck R.A. 1981. Brazilian Structural Provinces: An Introduction. Earth Science Review, 17(1-2):1-29. https://doi.org/10.1016/0012-8252(81)90003-9

Altschuler Z.S. 1973. The Weathering of Phosphate Deposits. In: Griffith E.J., Beeton A., Spencer J.M., Mitchell D.T. (Eds.). Geochemical and Environmental Aspects. Enviromental Phosphorus Handbook. New York: Willey, p. 33-96

Antonakos A., Liarokapis E., Leventouri T. 2007. Micro-Raman and FTIR Studies of Synthetic and Natural Apatites. Biomaterials, 28(19):3043-54. https://doi.org/10.1016/j.biomaterials.2007.02.028

Anzolin H.M. 2015. Mineralogia e Geoquímica do Perfil de Intemperismo do Carbonatito Três Estradas. Monography, Universidade Federal do Rio Grande do Sul, Porto Alegre, $116 \mathrm{p}$.

Burger Jr. C., Ribeiro M., Gerhardt A.L.B. 1988. On the Alkaline Rocks of Piratini, Rio Grande do Sul, Brazil. Paula-Coutiana, (2):81-112.

Barker D.S., Nixon P.G. 1989. High-Ca, Low Alkali Carbonatite Volcanism at Fort Portal, Uganda. Contributions to Mineralogy and Petrology, 103(2):166177. http://dx.doi.org/10.1007/BF00378502

Cerva-Alves T., Remus M.V.D., Dani N., Basei, M.A.S. 2017. Integrated Field, Mineralogical and Geochemical Characteristics of Caçapava do Sul Alvikite and Beforsite Intrusions: A new ediacaran carbonatite complex in southernmost Brazil. Ore Geology Reviews, 88:352-369. http://dx.doi. org/10.1016/j.oregeorev.2017.05.017

Chemale Jr. F. 2000. A Evolução Geológica do Escudo Sul-Rio-Grandense. In: Holz M., De Ros L.F. (Eds.). Geologia do Rio Grande do Sul. Porto Alegre, UFRGS, p. 13-52.
Cordani U.G., Brito-Neves B.B. 1982. The Geologic Evolution of South America During the Archean and Early Proterozoic. Revista Brasileira de Geociências, 12(1-3):78-88

Deer W.A., Howie R.A., Zussman J. 1992. An Introduction to the RockForming Minerals. 2. ed. Harlow, Longman, 695 p.

Elliot J.C. 1994. Structure and Chemistry of the Apatites and Other Calcium Orthophosphates. Amsterdam, Elsevier.

ESRI. 2009. "World Imagery" [basemap]. Scale Not Given. "World Imagery”. Available at: <http://www.arcgis.com/home/item.html ?id=10df2279f9684e4a9f6a7f08febac2a9>. Accessed on: February $25,2018$.

Fernandes L.A.D., Tommasi A., Porcher C.C. 1992. Deformation Patterns in the Southern Brazilian Branch of the Dom Feliciano Belt: A reappraisal. Journal of South American Earth Sciences, 5(1):77-96. https://doi. org/10.1016/0895-9811(92)90061-3

Ferrari V.C. 2000. Fosfatos Primários e Secundários nos Perfis de Intemperismo Sobre os Maciços Alcalino-carbonatíticos de Juquiá (SP), Anitápolis (SC) e Tapira (MG). Dissertation, Universidade de São Paulo, São Paulo, 261 p.

Gastal M.C.G., Ferreira F.J.F. 2013. Discussão dos Processos de Construção do Complexo Granítico São Sepé, RS: feições geológicas e petrográficas. Pesquisas em Geociências, 40(3):233-257. https://doi. org/10.22456/1807-9806.43440

Gomes C.B., Comin-Chiaramonti P., Azzone R.G., Ruberti E., Rojas G.E.E. 2018. Cretaceous Carbonatites of the Southeastern Brazilian Platform: a Review. Brazilian Journal of Geology, 48(2):317-345. https://dx.doi. org/10.1590/2317-4889201820170123

Goulart A.R. 2014. Geologia e Petrografia do Picrito do Boqueirão e Sua Correlação com outras Rochas Máficas Ultramáficas no SW do Escudo SulRiograndense. Monography, Universidade Federal do Rio Grande do Sul, Porto Alegre, $85 \mathrm{p}$.

Grazia C.A., Toniolo J.A., Parisi G., Muller E.L., Dressler V.L. 2011. Prospecção Hidrogeoquímica no Carbonatito Três Estradas, RS. In: Congresso Brasileiro de Geoquímica, 13., Gramado. Anais... Gramado, SBGq, p. 1769-1772.

Grunenwald A., Keyser C., Sautereau A.M., Crubezy E., Ludes B., Drouet C. 2014. Revisiting Carbonate Quantification in Apatite (Bio)Minerals: A Validated FTIR Methodology. Journal of Archaeological Science, 49(1):134141. http://dx.doi.org/10.1016/j.jas.2014.05.004 
Hartmann L.A. 1998. Deepest Exposed Crust of Brazil- Geochemistry of Paleoproterozoic Depleted Santa Maria Chico Granulites. Gondwana Research, 1(3-4):331-341. https://doi.org/10.1016/ S1342-937X(05)70849-2

Hartmann L.A., Leite J.A.D., Silva L.C., Remus M.V.D., McNaughton N.J., Groves D.I., Fletcher I.R., Santos J.O.S., Vasconcellos M.A.Z. 2000. Advances in SHRIMP Geochronology and their Impact on Understanding the Tectonic and Metallogenic Evolution of Southern Brazil. Australian Journal of Earth Sciences, 47(5):829-844. https://doi. org/10.1046/j.1440-0952.2000.00815.x

Iglesias C.M.F. 2000. Análise Integrada de Dados Geológicos e Estruturais Para a Prospecção de Ouro na Região De Torquato Severo (RS). Dissertation, Universidade Federal do Rio Grande do Sul, Porto Alegre, 118 p.

Ignacio C., Muñoz M., Sagredo J. 2012. Carbonatites and Associated Nephelinites From São Vicente, Cape Verde Islands. Mineralogical Magazine, 76(2):311-355. https://doi.org/10.1180/ minmag.2012.076.2.05

Jost H, Hartmann L.A. 1984. Província Mantiqueira - Setor Meridional. In: Almeida F.F.M. \& Hasui Y. (Eds.). O Pré-Cambriano do Brasil. São Paulo, Edgard Blücher, p. 345-368.

Kohn M.J., Rakovan J., Hughes J.M. 2002. Phosphates: Geochemical, Geobiological, and Materials Importance. United States, Mineralogical Society of America, 742 p. (Reviews in Mineralogy and Geochemistry, 48).

Lapido-Loureiro F.E.L., Castro N.F., Silva R.E.C. 2005. Brasil: Recursos Minerais e a Produção de Fosfatos, Fosfatos, Minerales para la Agricultura em Latinoamérica. p. 53-72.

Laux J.H. 2017. Geologia e Recursos Minerais da Folha Lagoa da Meia Lua - SH. 21-Z-B-VI. Escala 1:100.000. Estado do Rio Grande do Sul. Porto Alegre, CPRM, $255 \mathrm{p}$.

Luzardo R., Fernandes L.A.D. 1990. Análise Estrutural do Lineamento de Ibaré Parte I: Filitos de Ibaré - Greenstone Belt ou Cobertura Cratônica Deformada? Acta Geológica Leopoldensia, 13(30):25-36

Nardi L.V.S., Hartmann L.A. 1979. O Complexo Granulítico Santa Maria Chico do Escudo Sul-riograndense. Acta Geológica Leopoldensia, 6:45-75.

Naumann M.P., Hartmann L.A., Koppe J.C., Chemale Jr. F. 1984 Sequências Supra-crustais, Gnaisses Graníticos, Granulitos e Granitos Intrusivos da Região de Ibaré-Palma, RS: Geologia, Aspectos Estratigráficos e Considerações Geotectônicas. In: Congresso Brasileiro de Geologia, 33. Rio de Janeiro. Anais... p. 2417-2425

Neto A.A. 1991. Evolução Supérgena das Rochas Carbonáticas Ricas em Apatita do Complexo Alcalino de Juquiá (SP). Dissertation - Universidade de São Paulo, São Paulo, 261 p.

Oliveira S.M.B., Imbernon R.A.L. 1998. Weathering Alteration and Related REE Concentration in the Catalão I Carbonatite Complex, Central Brazil. Journal of South American Earth Sciences, 11(4):379-388. https://doi. org/10.1016/S0895-9811(98)00024-8

Parisi G.N., Toniolo J.A., Grazia C.A., Pinto L.G.R. 2010. Prospecção de Fosfato no Rio Grande Do Sul. In: Congresso Brasileiro de Geologia, 30., Belém do Pará. Anais... Pará, SBG, 236 p.

Penel G., Leroy G., Rey C., Bres E. 1998. Microraman Spectral Study of the $\mathrm{PO}_{4}$ and $\mathrm{CO}_{3}$ Vibrational Modes in Synthetic and Biological Apatites. Calcified Tissue International, 63(6):475-481. https://doi.org/10.1007/ s002239900561
Philipp R.P., Gireli T., Lopes R.C., Sander A. 2017. Geologia do Complexo Granulítico Santa Maria Chico na Região de Fontouras, Dom Pedrito, RS: Significado Tectônico e Implicações Sobre a Evolução do Cráton Rio de La Plata, RS, Brasil. Geologia USP (In press).

Philipp R.P., Pimentel M.M., Chemale Jr. F. 2016. Tectonic Evolution of the Dom Feliciano Belt in Southern Brazil: Geological Relationships and U-Pb Geochronology. Brazilian Journal of Geology, 46(Suppl. 1):83-104. http:// dx.doi.org/10.1590/2317-4889201620150016

Rehman I., Bonfield W. 1997. Characterization of Hydroxyapatite and Carbonated Apatite by Photo Acoustic FTIR Spectroscopy. Journal of Materials Science, 8(1):1-4.https://doi.org/10.1023/A:1018570213546

Rocha A., Dorneles N.T., Gindri M.D., Vargas J.M., Cerva-Alves T., Benetti F.A. 2013. Descoberta dos Carbonatitos Picada dos Tocos e Passo Feio e o Potencial Para Fosfato e ETRs, Caçapava do Sul, Rio Grande do Sul. In: Brazilian Symposium of Metallogeny - The New Brazilian Mineral Deposits, 3., Gramado. Boletim de Resumos.

Ruppel K.M.V., Dani N., Remus M.V.D., Ronchi L.H., Gomes M.E.B., Senhorinho E. 2018. Temperature and Pressure in Environment of Epithermal Alteration - A Case Study at The Ibaré Lineament - RS, Brazil. Brazilian Journal of Geology, 48(4):685-702. http://dx.doi. org/10.1590/2317-4889201820180009

Schwab R.G., Herold H., Götz C., Oliveira N.P. 1989. Compounds of the Crandallite Type: Synthesis and Properties of Pure Goyazite, Gorceixite And Plumbogummite. Neues Jahrbuch für Mineralogie Monatshefte, 3:113-126.

Serviço Geológico do Brasil (CPRM). 2006. Mapa Geológico do Rio Grande do Sul: Porto Alegre, map, color, $72 \times 85,5 \mathrm{~cm}$. Scale: 1:750,000. Brasil, Programa Geologia Brasil.

Stormer Jr. J.C., Pierson M.L., Tacker R.C. 1993. Variation of F and Cl X-ray Intensity Due to Diffusion in Apatite During Electron Microprobe Analysis. American Mineralogist, 78:641-648.

Straaten P.V. 2002. Rocks for Crops: Agrominerals of Sub-Sahara Africa. Nairobi, Kenya, ICRAF, 338 p.

Toledo M.C.M., Ferrari V.C., Alcover Neto A., Fontan F., Martin F., Santos C.N., Carvalho F.M.S. 2002. Fosfatos Aluminosos com Ferro do Grupo da Crandalita nas Coberturas Lateríticas de Catalão I, Juquiá e Tapira (Brasil) e Chiriguelo (Paraguai). Revista Brasileira de Geociências, 32(4):393-406.

Toledo M.C.M., Lenharo S.L.R., Ferrari V.C., Fontan F., Parseval P., Leroy G. 2004. The Compositional Evolution of Apatite in the Weathering Profile of the Catalão I Alkaline-Carbonatitic Complex, Goias, Brazil. The Canadian Mineralogist, 42(4):1139-1158. https://doi.org/10.2113/ gscanmin.42.4.1139

Toniolo J.A., Parisi G.N., Grazia C.A., Reischl J.L. 2010. Prospecção de Fosfato na Região de Três Estradas, Lavras do Sul, RS. In: Simpósio Brasileiro de Exploração Mineral, 4., Ouro Preto. Proceedings...

Toniolo J.A., Remus M.V., Parisi G.N., Dani N. 2013. Dois Eventos Carbonatíticos Temporalmente Distintos no RS: Tipos Linear e Central. In: Simpósio Sul-brasileiro de Geologia, 8., 2013, Porto Alegre. Abstracts...

Vieillard P., Tardy Y., Nahon D. 1979. Stability Fields and Aluminum Phosphates: Parageneses in Lateritic Weathering of Argilaceous Phosphatic Sediments. American Mineralogist, 64(5-6):626-634.

Walter A.V., Nahon D., Flicoteaux R., Girard J.P., Melfi A. 1995. Behaviour of Major and Trace Elements and Fractionation of REE Under Tropical Weathering of a Typical Apatite-Rich Carbonatite from Brazil. Earth and Planetary Science Letters, 136(3-4):591-602. https://doi. org/10.1016/0012-821X(95)00195-I 